Article

\title{
Women Entrepreneurship in International Trade: Bridging the Gap by Bringing Feminist Theories into Entrepreneurship and Internationalization Theories
}

\author{
Mansura Akter, Mahfuzur Rahman $(D)$ and Dragana Radicic *(D) \\ Department of Accounting, Finance and Economics, Lincoln International Business School, University of \\ Lincoln, Lincoln LN67TS, UK; makter@lincoln.ac.uk (M.A.); marahman@lincoln.ac.uk (M.R.) \\ * Correspondence: dradicic@lincoln.ac.uk
}

Received: 6 October 2019; Accepted: 5 November 2019; Published: 7 November 2019

check for updates

\begin{abstract}
Participation of women-owned small and medium-sized enterprises (SMEs) in international trade is gaining more importance in the transformation of institutional changes. Although women entrepreneurs contribute to the social and economic development, the role of social, cultural, and legal institutions in fostering women entrepreneurship is still debatable. This argument remains controversial as there is no single theory that has explained the phenomenon of women-owned firms in international trade. Because of the missing link between gender sensitivity and the existing theories of entrepreneurship and internationalization, there is a significant research gap. To fill up this research gap, this study revisited existing theories from three research domains: feminism, entrepreneurship, and internationalization. Factors derived from revisiting theories of entrepreneurship and internationalization were evaluated based on findings from the review of the feminist theories. Finally, key parameters were selected to assess the internationalization of women-owned SMEs, which require future empirical investigation.
\end{abstract}

Keywords: feminism theories; internationalization; female entrepreneurship; SMEs; gender sensitivity

\section{Introduction}

Research attention devoted to women entrepreneurs has been increased in recent years as female entrepreneurship is considered as a potential source of economic and social development [1-4]. According to the international labor organization [5], more than $42 \%$ of all operating companies in the formal economy worldwide are led by women entrepreneurs. The world trade organization (WTO) [6] stresses that investing in women and empowering women to invest in themselves is a risk-free venture, as they give back ten times more what they get from society. Moreover, confirming women's participation in the economic mainstream is crucial for achieving sustainable development goals (SDGs) [5-7]. Therefore, recent research interests focus on what women entrepreneurs do and do not accomplish compared to men and then filters into the "who," "why," "where," and "how" questions that go along with understanding the foundation, development, and growth of the businesses [3].

Although research evidence confirms that women play a vital role in economic development, a range of barriers limits their opportunities [8]. It is also true in the case of women's participation in international trade. According to the International Trade Centre (ITC [9]), only 15\% of exporting firms are led by women entrepreneurs, though $40 \%$ of SMEs worldwide are women-owned businesses. The WTO [8] declares that it is crucial to take actions to better integrate women into the international trading system. Keeping the same goals in mind, ITC targets to bring at least one million new women entrepreneurs to international markets by 2020 [10].

However, globalization, educational advancement, technological developments, and transportation developments have created huge opportunities and challenges. To achieve these 
opportunities and face these challenges, we need better participation of both male and female entrepreneurs. Otherwise, some of the opportunities will be bypassed, and some challenges will be unsurmountable. As the factors associated with women entrepreneurs are significantly different from male entrepreneurs [11-16], it is a timely response to identify these barriers to take an effective action plan. Consequently, this theoretical study focused on developing an effective evaluation to identify the gender-sensitive challenges that women entrepreneurs face in international trade by revisiting theories from three branches: feminism, entrepreneurship, and internationalization. Given the theoretical nature of our study, we derived our conclusions from a literature review and not from empirical evidence or specific cases of internationalization.

Research on understanding the role of women in business is well documented in some studies, such as Gundlach and Sammartino [4], international finance corporation [17], and WTO [8]. Joshi et al. [18] reviewed the evolution of research on female entrepreneurship in the last 50 years. Initially, the focus was on realizing that women face inequality in the business environment; then, the focus shifted to identifying and understanding the barriers faced by women in business, and finally, the topics of gender differences and diversity in teams were explored. More recently, attention is on the stakeholder effect of women-owned businesses compared to that of men [2].

Although existing studies discussed the evolution of female entrepreneurship and the role of women entrepreneurs, further development is needed in some areas, such as women attitude towards international trade; gender divide in trade policy preferences [19]; a structure of fair trade and women exclusion [20]; barriers and drivers to women entrepreneurs in developing their international businesses and participating in exporting $[6,9,17]$; and bringing gender consciousness to the development of the entrepreneurial leadership theory [1,21-24].

Farashah [25] argued that though most researchers use gender as a socially constructed factor, its implications are not fully explored, as it is important to explore social and ethical considerations that motivate women entrepreneurs. Moreover, understanding women's strengths and weaknesses is important in generating greater value for society in the long run [2]. Besides, the implication of gender issues in the context of internationalization of women-owned small firms needs further attention [20]. However, there is a paucity of research that incorporates gender issues in understanding the internationalization of women-owned SMEs, particularly in relation to why women face different sets of challenges or why they approach the same situations differently compared to men, although they run their business within the same business atmosphere. To answer this question, this study offered a gender-sensitive approach by incorporating insights from theories related to feminism, entrepreneurship, and internationalization to examine women-led business phenomena in the international markets.

A question may come to mind as to why a separate attitude is important to examine women-led businesses. If we use a common yardstick to evaluate both male-owned and female-owned firms, it will be just like prescribing a single medicine for all types of diseases. According to Buttner and Moore [26], several existing studies have conceptual flaws because they evaluate values, thought processes, and experiences of women business leaders by comparing them to their male counterparts. More specifically, women entrepreneurs are judged according to masculine values [27]. On the one hand, existing research on entrepreneurship shows that men have more success in pursuing business growth than women [28], and women fear to control business growth and sometimes deliberately choose to prevent their business from growing [21]. These findings signify that the problems holding back the growth of women-owned businesses originate in women's characteristics. For example, Meyerson and Kolb [29] reported that attributes associated with femininity (e.g., nurturing, listening, emoting, and relating) place women in a disadvantaged position. Moreover, research shows that there is a connection between emotions, cognition, and entrepreneurial decision making [30,31]. On the other hand, some scholars have noted that gendered institutions exert extra challenges for women business owners [32]. Therefore, researching female entrepreneurship should encompass both their characteristics as well as institutional, economic, and political environment. 
Research in the field of gender and trade should incorporate not only insights from the entrepreneurial and internationalization theories but also feminist theories. Specifically, a conceptual framework encompassing all three streams of research should take into account what feminist theories identify as problems and challenges that women face in the society, what entrepreneurial theorists say about the requirements to be successful as an entrepreneur, and what internationalization theorists say about forces that trigger firms to participate in international markets. Is there a link between what feminist theories posit about women's position in society and their socialization process with their behavior as a business owner? Therefore, to find an approach to evaluate women's situation in business, especially when they are involved in international business, this study revisited theories related to feminism, entrepreneurship, and internationalization. Moreover, entrepreneurship and internationalization theories do not incorporate valuable insights from feminist theories [33,34]. For example, scholars in the field of trade and gender argue that feminist theories are necessary to provide clear insights into understanding the women-led business phenomena [1,21,34-36]. Besides, diversity in context and theories could vary by gender, business sectors, and regions of the world [21]. Moreover, Wallace [37] argued that the strategic framework established by previous researchers has failed to tackle gender inequalities due to the dominant use of 'rational economic man (REM)' discourse in policy and mainstream business arena. Assessing women entrepreneurs' performances by using a gender-blind approach portrays a picture that women are less competitive in international business development and growth, as found in Alves et al. [2]. Such findings would create fears for women entrepreneurs and discourage them from the advancement in business rather than help them to build confidence.

Against this setting, this study offered gender-sensitive parameters by incorporating insights from theories related to feminism, entrepreneurship, and internationalization, which aim to fill in the research gap in women-led business phenomena and could be interpreted as a springboard for future research and policymaking to ensure gender equality in the economic mainstream. Besides, this study explored why, despite substantial government funding to business support, the numbers of women entrepreneurs in international trade remains significantly low. This theoretical and literature-based work contributed to conceptualizing the connection of the notions of 'being' entrepreneur, 'doing' entrepreneurship, and 'becoming' women in business.

\section{Theoretical Background}

Although researchers in the entrepreneurship field offer several conceptual frameworks by reframing entrepreneurship from feminist perspectives [22,33,34,38-43], such a framework has not been developed in the context of internationalization of women-owned firms. The notions that firms expanding business overseas markets face more challenges and have a greater impact on their business development have strong evidence in the internationalization literature. This is true for women-owned firms too. For example, women-owned firms involved in the global marketplace have greater revenues, are more optimistic about their business prospects, and are more focused on business expansion compare to women-owned firms doing business domestically [6,44]. However, women entrepreneurs' journey in international trade is not the same as for their counterparts $[2,10,45]$. Muñoz-Bullón, Sánchez-Bueno, and Vos-Saz [46] found that entrepreneurial personality traits, such as proactiveness, risk-taking, and innovativeness, have a significant influence on the entrepreneur's entry into foreign markets.

As no single theory of entrepreneurship or internationalization describes female entrepreneurship, especially international female entrepreneurship, this study considered entrepreneurship theories and internationalization theories as a lens to develop the epistemology and feminist theories as an ontology to propose an approach for scrutinizing women-owned firms participating in international trade (see Figure 1). 


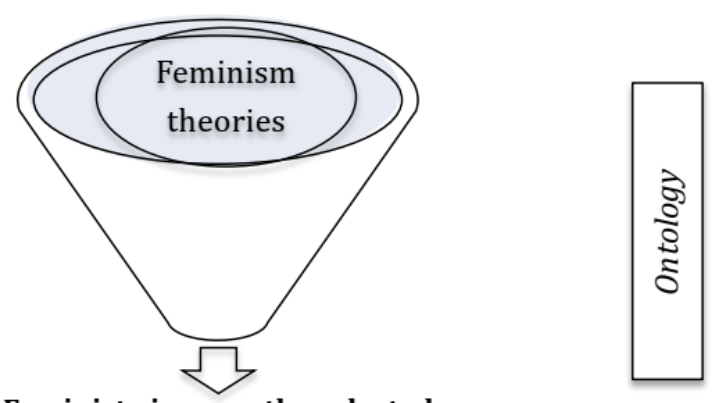

Feminist views on the selected parameters
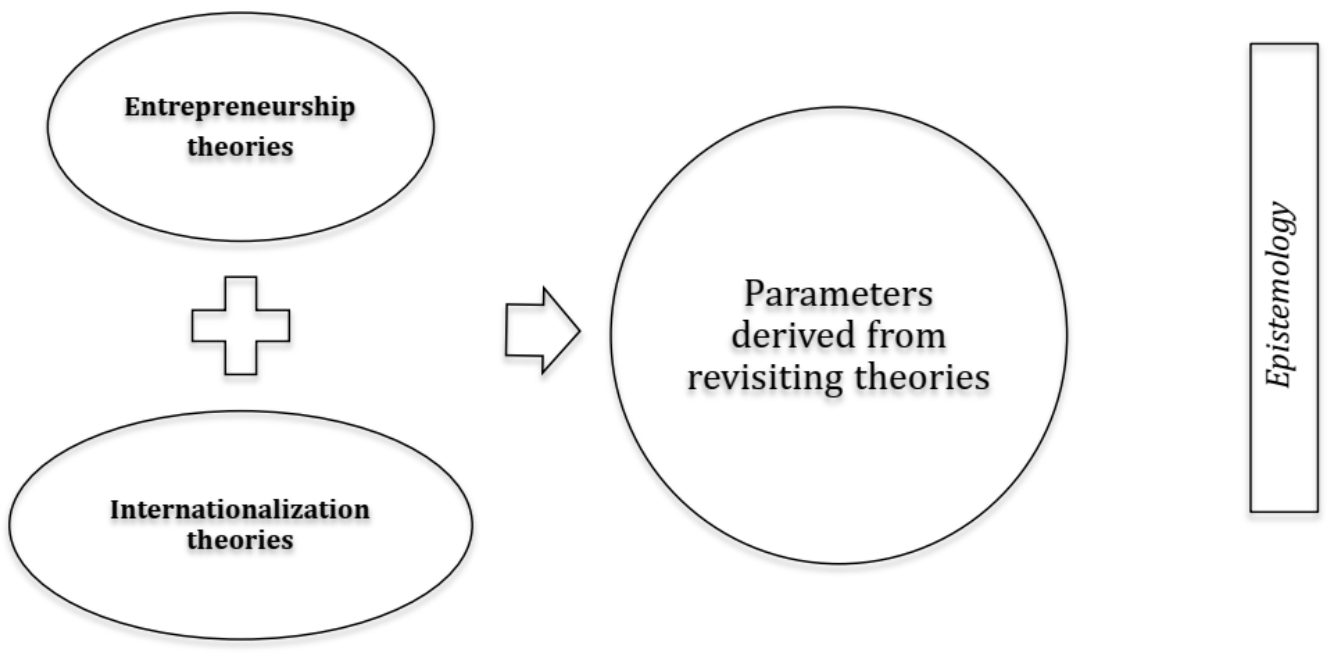

Figure 1. Epistemology and ontology of the proposed parameters.

\section{Methodology}

To develop parameters for evaluating internationalization of women-owned firms, this study aimed to explore the issues that have a direct or indirect influence on the strategic behavior of women-owned SMEs in going beyond the border to be a competent actor in the competitive globalized business environment. In proposing this gender-sensitive approach, we followed the guidelines given by Grant and Osanloo [47]. They suggested that, in developing a framework for research, researchers should begin by identifying researchers' belief and review several theories that intersect with their epistemological values and broaden their way of thinking about the concepts in the focal study. We used Dubin's [48] theory building framework as a preliminary step to propose a gender-aware internationalization theory. Dubin's framework of theory building is well accepted in the field of marketing, management, and organization theories. There are eight steps in the methodology, and the first five steps are related to building structural components of a theory, and the last three steps are related to empirical validation of the theory. As theory building and empirical research require separate efforts, Ardichvili, Cardozo, and Ray [49] suggested that each of these phases could be conducted as separate distinct research efforts. Keeping this in mind, this study attempted to complete the first two phases: 1) identifying the units (concepts) of the theory, and 2) the law of interaction (i.e., interaction among concepts) (see [48]). In addition, a brief literature review was conducted (as suggested by [47]) to find support regarding how the units/parameters identified connect to challenges and opportunities women entrepreneurs face in the business world.

In exploring the factors that directly or indirectly influence the internationalization of women-led small business, in the first stage, theories related to internationalization, entrepreneurship, and feminism were revisited. In this stage, key factors were identified from the review of entrepreneurship theories as well as internationalization theories, which influence the internationalization of small businesses. In the second stage, some factors were derived that might hinder or drive the internationalization of 
small businesses. Finally, key issues identified from the review of feminist theories were used as a spotlight to evaluate the feminist views on the selected parameters.

\section{Identifying Success Factors for Entrepreneurship: Revisiting Entrepreneurship Theories}

Over time, numerous theories of entrepreneurship have been put forwarded [33]. Theories of entrepreneurship help academics to understand the entrepreneurial process and to predict who will become an entrepreneur and what conditions force them to entrepreneurship. There are two bipolar views on entrepreneurship; while one explicitly focuses on actors (entrepreneurs), others emphasize the actors' environment. Given that early entrepreneurship theories examine entrepreneurship from the institutional perspective [50-52], Grebel et al. [53] argued that a modern evolutionary approach should be developed by incorporating the human capital theory [54] and the social network theory [55]. However, no entrepreneurship theory is developed from the feminist perspective, and no feminist theory covers the entrepreneurship discipline completely [33]. Hurley [33] also noted that a feminist theory might be able to expand entrepreneurship theories by providing new insights by examining a historical context in which these theories emerged, the research methods in which the theories are grounded, and the assumptions underlying the theories.

Consequently, if only prevailing entrepreneurship theories are considered in developing an analytical framework to examine the internationalization of women-owned SMEs, some valuable insights will go unnoticed. Thus, prevailing entrepreneurship theories were revisited here along with the feminist theories and internationalization theories to construct an analytical framework that would be able to provide complete insights of the research questions. For this purpose, entrepreneurship theories from the six diverse viewpoints (economic, psychological, sociological, anthropological, opportunity-based, and resource-based) were reviewed to identify factors associated with success in entrepreneurial actions. In the light of this review, key assumptions, implications of assumptions of each theory, and factors used in existing entrepreneurial research were summarized, as shown in Table 1. Moreover, based on the review findings, some associated key factors were derived that influence women's activities, particularly business activities, in society and might influence the internationalization of women-owned SMEs. 
Table 1. Summary of the entrepreneurship theories and derived factors.

\begin{tabular}{|c|c|c|c|c|c|}
\hline \multirow{2}{*}{ Theories } & \multirow{2}{*}{ Key Assumptions } & \multicolumn{3}{|c|}{ Evidence from Literature } & \multirow{2}{*}{ Derived Factors } \\
\hline & & Contributors & Identified Factors & Implications & \\
\hline \multicolumn{6}{|c|}{ Economic Entrepreneurship Theories } \\
\hline (a) Classical Theory & $\begin{array}{l}\text { Assume the virtues of free trade, } \\
\text { specialization, and competition initiate } \\
\text { entrepreneurship. } \\
\text { The directing role of the entrepreneur in the } \\
\text { context of production and distribution of } \\
\text { goods in a competitive marketplace. } \\
\text { Highlights that entrepreneurial success } \\
\text { depends on the internal ability to judge and } \\
\text { forecast a particular situation. }\end{array}$ & $\begin{array}{l}\text { Cantillon [56] } \\
\text { Smith [57] } \\
\text { Ricardo [58] }\end{array}$ & $\begin{array}{l}\text { Speculation } \\
\text { Free trade } \\
\text { Specialization and } \\
\text { competition }\end{array}$ & $\begin{array}{l}\text { Free trade opportunities and competition } \\
\text { trigger entrepreneurship. }\end{array}$ & $\begin{array}{l}\text { Free trade opportunity } \\
\text { and competition }\end{array}$ \\
\hline \multirow{3}{*}{ (b) Neo-classical Theory } & \multirow{3}{*}{$\begin{array}{l}\text { Economic phenomena could be relegated to } \\
\text { instances of pure exchange. } \\
\text { The economic system consists of exchange } \\
\text { participants, exchange occurrences, and the } \\
\text { impact of results of the exchange on other } \\
\text { market actors. }\end{array}$} & Jevons [59] & $\begin{array}{l}\text { Exchange and marginal } \\
\text { utility }\end{array}$ & $\begin{array}{l}\text { Exchange creates enough impetus for } \\
\text { entrepreneurship. }\end{array}$ & Exchange/export of goods \\
\hline & & Marshall [60] & $\begin{array}{l}\text { Coordination, innovation, } \\
\text { arbitration }\end{array}$ & & \\
\hline & & $\begin{array}{l}\text { Hawley [61] cited in } \\
\text { Hebert and Link [62] }\end{array}$ & Uncertainty bearer & & Risk-taking ability \\
\hline $\begin{array}{l}\text { (c) Austrian Market } \\
\text { Process (AMP) }\end{array}$ & $\begin{array}{l}\text { Highlights the importance of human action } \\
\text { in the context of an economy of knowledge. } \\
\text { Entrepreneurship is considered as a driver of } \\
\text { market-based systems. } \\
\text { Three concepts of AMP: arbitraging market, } \\
\text { alertness to profit-making opportunities, } \\
\text { ownership is distinct from entrepreneurship. }\end{array}$ & Schumpeter [52] & $\begin{array}{l}\text { Human actions in the } \\
\text { knowledge economy } \\
\text { Arbitraging (searching) } \\
\text { market for opportunities } \\
\text { Alertness to profit-making } \\
\text { opportunities. }\end{array}$ & $\begin{array}{l}\text { Opportunity seeking is important for } \\
\text { entrepreneurial growth and expansion. }\end{array}$ & $\begin{array}{l}\text { Knowledge as human } \\
\text { capital; alertness to } \\
\text { profit-making } \\
\text { opportunities }\end{array}$ \\
\hline \multicolumn{6}{|c|}{ Psychological Entrepreneurship Theories } \\
\hline \multirow[t]{2}{*}{$\begin{array}{l}\text { (a) Personality Traits } \\
\text { Theory }\end{array}$} & \multirow{2}{*}{$\begin{array}{l}\text { Entrepreneurs' characteristics give us a clue } \\
\text { or an understanding of these traits or inborn } \\
\text { potentials. } \\
\text { Personality traits help explaining or to make } \\
\text { an inference from behavior. }\end{array}$} & Rotter [63] & Locus of control & $\begin{array}{l}\text { Entrepreneur's success comes from his/her } \\
\text { abilities and also support from outside. }\end{array}$ & $\begin{array}{l}\text { Support from family and } \\
\text { society }\end{array}$ \\
\hline & & Simpeh [64] & $\begin{array}{l}\text { Internal locus of control } \\
\text { (entrepreneur's abilities) } \\
\text { External locus of control } \\
\text { (support from outside) } \\
\end{array}$ & $\begin{array}{l}\text { Locus of control had negative influence on } \\
\text { entrepreneurial inclination. } \\
\text { This theory also stresses that outside } \\
\text { support can be constraint or driver. }\end{array}$ & $\begin{array}{l}\text { Entrepreneur's abilities } \\
\text { (locus of control) }\end{array}$ \\
\hline $\begin{array}{l}\text { (b) Need for Achievement } \\
\text { Theory }\end{array}$ & $\begin{array}{l}\text { Human beings need to succeed, accomplish, } \\
\text { excel, or achieve. } \\
\text { Entrepreneurs are driven by this need to } \\
\text { achieve and excel. }\end{array}$ & McClelland [65] & Achievement motivation & $\begin{array}{l}\text { Risk-taking and innovativeness, need for } \\
\text { achievement, and the tolerance for } \\
\text { ambiguity have a positive and significant } \\
\text { influence on entrepreneurial inclination. }\end{array}$ & Need for achievement \\
\hline
\end{tabular}


Table 1. Cont.

\begin{tabular}{|c|c|c|c|c|c|}
\hline \multirow{2}{*}{ Theories } & \multirow{2}{*}{ Key Assumptions } & \multicolumn{3}{|c|}{ Evidence from Literature } & \multirow{2}{*}{ Derived Factors } \\
\hline & & Contributors & Identified Factors & Implications & \\
\hline \multicolumn{6}{|c|}{ Sociological Entrepreneurship Theory } \\
\hline $\begin{array}{l}\text { (a) Weber's Sociological } \\
\text { Theory }\end{array}$ & $\begin{array}{l}\text { Religious imperatives of Calvinism drive } \\
\text { entrepreneurs by giving moral energy. }\end{array}$ & Weber [66] & $\begin{array}{l}\text { Religious and social } \\
\text { values }\end{array}$ & $\begin{array}{l}\text { Religious beliefs and values influence } \\
\text { entrepreneurial actions. }\end{array}$ & Religious norms \\
\hline $\begin{array}{l}\text { (b) Theory of Withdrawal } \\
\text { of Status Respect }\end{array}$ & $\begin{array}{l}\text { Entrepreneurship is triggered when a social } \\
\text { group loses status as compared to other } \\
\text { groups in a society. }\end{array}$ & Dana [67] & $\begin{array}{l}\text { Loss of status/Loss of } \\
\text { social recognition/ } \\
\text { Disrespect from society }\end{array}$ & $\begin{array}{l}\text { Disrespect from the dominant social group } \\
\text { triggers a personality change (creativity) } \\
\text { that encourages entrepreneurial behaviors. }\end{array}$ & Need to gain social status \\
\hline $\begin{array}{l}\text { (c) Theory of Moral } \\
\text { Dimension of Culture }\end{array}$ & $\begin{array}{l}\text { The moral dimension of culture legitimates } \\
\text { general principles of business behavior and } \\
\text { motivates entrepreneurs to make } \\
\text { commitments of various kinds. }\end{array}$ & Casson [68] & $\begin{array}{l}\text { The moral dimension of } \\
\text { culture }\end{array}$ & $\begin{array}{l}\text { Commitments to tell the truth, respecting } \\
\text { other people's property and interests, and } \\
\text { obeying the legal process may affect } \\
\text { business activities. }\end{array}$ & $\begin{array}{l}\text { Social relationships and } \\
\text { bonds } \\
\text { Experiences } \\
\text { Government legislation }\end{array}$ \\
\hline (d) Social Contexts & $\begin{array}{l}\text { Highlights four social contexts that relate to } \\
\text { entrepreneurial opportunity, } \\
\text { (a) social network, (b) life course stage, (c) } \\
\text { ethnic identification, (d) population ecology. }\end{array}$ & Reynolds [69] & $\begin{array}{l}\text { Social relationships and } \\
\text { bonds } \\
\text { Experiences of people } \\
\text { Sociological background } \\
\text { (identity) } \\
\text { Government legislation, } \\
\text { customers, employees, } \\
\text { and competition }\end{array}$ & $\begin{array}{l}\text { Acts as a push/pull factor to an } \\
\text { entrepreneurial decision. }\end{array}$ & $\begin{array}{l}\text { Social relationships and } \\
\text { bonds } \\
\text { Experiences } \\
\text { Sociological background } \\
\text { (identity) } \\
\text { Government legislation } \\
\text { Availability of customers } \\
\text { and competitors }\end{array}$ \\
\hline \multicolumn{6}{|c|}{ Anthropological Entrepreneurship Theory } \\
\hline \multicolumn{6}{|c|}{ Opportunity-Based Entrepreneurship Theory } \\
\hline $\begin{array}{l}\text { Opportunity-Based } \\
\text { Entrepreneurship Theory }\end{array}$ & $\begin{array}{l}\text { The entrepreneur always searches for a } \\
\text { change, responds to it, and exploits it as an } \\
\text { opportunity. } \\
\text { The entrepreneur has a pursuit of } \\
\text { opportunity without regard to resources } \\
\text { currently controlled. } \\
\text { Assumes the entrepreneur's personality } \\
\text { traits, social networks, and prior knowledge } \\
\text { as antecedents of entrepreneurial alertness to } \\
\text { business opportunities. }\end{array}$ & $\begin{array}{l}\text { Drucker [74] } \\
\text { Stevenson and Jarillo [75] } \\
\text { Ardichvili et al. [49] }\end{array}$ & $\begin{array}{l}\text { Opportunity recognition } \\
\text { and exploitation } \\
\text { Resourcefulness and } \\
\text { opportunity exploitation } \\
\text { Entrepreneurial alertness }\end{array}$ & $\begin{array}{l}\text { Opportunity identification and } \\
\text { exploitation significantly drive firms' } \\
\text { behavior. } \\
\text { Access to information and knowledge } \\
\text { affects opportunities' recognition and } \\
\text { exploitation. } \\
\text { Entrepreneurial alertness, in its turn, is a } \\
\text { necessary condition for the success of the } \\
\text { opportunity identification triad: } \\
\text { recognition, development, and evaluation. }\end{array}$ & $\begin{array}{l}\text { Opportunity } \\
\text { identification } \\
\text { Information and } \\
\text { knowledge }\end{array}$ \\
\hline
\end{tabular}


Table 1. Cont

\begin{tabular}{|c|c|c|c|c|c|}
\hline \multirow{2}{*}{ Theories } & \multirow{2}{*}{ Key Assumptions } & \multicolumn{3}{|c|}{ Evidence from Literature } & \multirow{2}{*}{ Derived Factors } \\
\hline & & Contributors & Identified Factors & Implications & \\
\hline \multicolumn{6}{|c|}{ Resource-Based Entrepreneurship Theories } \\
\hline $\begin{array}{l}\text { Resource-Based } \\
\text { Entrepreneurship } \\
\text { Theories }\end{array}$ & $\begin{array}{l}\text { Different firms extract different services, } \\
\text { even from the same resources. } \\
\text { Firm-specific advantages are the result of } \\
\text { superior information. } \\
\text { Firm-specific advantages could drive high } \\
\text { returns. } \\
\text { Stresses the importance of financial, social, } \\
\text { and human resources. } \\
\text { Access to resources enhances the } \\
\text { individual's ability to detect and act upon } \\
\text { discovered opportunities. }\end{array}$ & $\begin{array}{l}\text { Becker [76] } \\
\text { Unger et al. [77] } \\
\text { Boudieu [78]; Coleman } \\
\text { [79]; Putnam [80] }\end{array}$ & $\begin{array}{l}\text { Human capital } \\
\text { (Knowledge, experience) } \\
\text { Social capital } \\
\text { (Social obligations, } \\
\text { connection, social } \\
\text { networks) } \\
\text { Financial capital }\end{array}$ & $\begin{array}{l}\text { Human capital is comprised of knowledge, } \\
\text { habits, social, and personality attributes, } \\
\text { such as creativity, that enhance an } \\
\text { individual's ability to perform a job to } \\
\text { produce economic value. } \\
\text { Social capital can be a source of useful } \\
\text { everyday information and of norms and } \\
\text { sanctions, which can facilitate certain } \\
\text { kinds of actions; however, it can also be } \\
\text { restrictive. } \\
\text { Financial capital helps people to exploit } \\
\text { entrepreneurial opportunities. }\end{array}$ & $\begin{array}{l}\text { Knowledge and } \\
\text { experience as human } \\
\text { capital } \\
\text { Social obligations } \\
\text { Social connections/ } \\
\text { networks } \\
\text { Social support and } \\
\text { encouragement } \\
\text { Financial illiteracy } \\
\text { Financial } \\
\text { information/advice. }\end{array}$ \\
\hline \multicolumn{6}{|c|}{ Recent Theory Related to Entrepreneurship } \\
\hline Effectuation Theory & $\begin{array}{l}\text { Focuses on the entrepreneurs' ability to } \\
\text { create opportunities together with network } \\
\text { partners. } \\
\text { Effectuation processes who the entrepreneur } \\
\text { is (entrepreneur's characteristics -traits, } \\
\text { tastes, and abilities), what they know } \\
\text { (knowledge corridors), and whom they } \\
\text { know (social networks). }\end{array}$ & Sarasvathy [81] & $\begin{array}{l}\text { Entrepreneur's } \\
\text { characteristics } \\
\text { Knowledge corridors } \\
\text { Social networks }\end{array}$ & $\begin{array}{l}\text { As this theory combines trait theory, } \\
\text { resource-based theory, and social network } \\
\text { theory, this theory is an effective one in } \\
\text { assessing the firm's international } \\
\text { development. }\end{array}$ & $\begin{array}{l}\text { Entrepreneur's abilities } \\
\text { Knowledge about foreign } \\
\text { markets } \\
\text { Networking with foreign } \\
\text { partners }\end{array}$ \\
\hline
\end{tabular}




\section{Identifying Success Factors for Internationalization: Revisiting Internationalization Theories}

In this section, three major domains of internationalization theories were reviewed to identify how internationalization has been understood and explained within prevailing theories and to determine the range of factors that foster SME internationalization. Small business internationalization has been observed from several different theoretical viewpoints in the prior literature. This review investigated theories from three distinctive perspectives of theorizing: economic, resource-based, and behavioral. This categorization does not mean three single unified models of internationalization, rather grouping theories under three headings according to their perspective resemblance. Two facts that influence such classification are: this grouping is conventional in the existing literature [82,83], and it helps to understand the unifying assumptions of theorizing [84].

\subsection{Internationalization: Economic Perspective}

An economic perspective, rooted in Smith [57] and Ricardo [58], still has a dominant explanatory power of internationalization. During Smith's and Ricardian time (18th and 19th century), trade between nations was the central point of analysis. Later, with the emergence of foreign direct investment (FDI), the unit of analysis has been moved from a nation to a firm level (e.g., multinational enterprises-MNEs). However, in the era of trade liberalization, where small firms or even sole proprietors can engage in trade, the research interest has shifted to a small business level analysis (e.g., SMEs; micro, small and medium-sized enterprises-MSMEs).

Four common aspects among theories developed from economic perspectives are: a) conceptualizing internationalization as an independent phenomenon, considering it as a profit-maximizing tool for risk-taking; b) placing firms' distinctive advantage central to internationalization; and c) conjecturing rationally [84]. Although the economic view of internationalization shares some common assumptions, these theories vary both in terms of their emphasis and how they ground central assumptions of theorizing. The internationalization theories from the economic perspectives are: (1) the monopolistic advantage theory; (2) the product life cycle theory; (3) the internalization theory; (4) the eclectic paradigm; and (5) the resource-based view of internationalization [83,84].

\subsection{Internationalization: Resource-Based View}

During the 1990s, the resource-based view of the firm (RBV) became the dominant paradigm in strategic planning [85]. Later, it has become an influential approach in internationalization research [86]. Hoskisson et al. [87] claimed that RBV is considered as one of the top three most useful theories helpful for understanding firms' strategy in emerging economies [88].

RBV focuses on a firm's internal resources. Specifically, if a firm's resources are valuable, rare, imperfectly imitable, and imperfectly sustainable, then these resources create competitive advantage of the focal firm [89]. A firm's resources can be divided into tangible and intangible. The former includes land, buildings, materials, and money, while the latter consists of competencies, knowledge, capabilities, attitudes, relationships, and reputation of the firm [90]. Bloodgood et al. [91] revealed that firms with a unique set of resources or spare resources are more likely to be international.

\subsection{Internationalization: Behavioral Perspective}

During the 1970s, behavioral theories of internationalization appeared as an alternative perspective to the economic view of internationalization. Theories under this heading are termed as behavioral, as these theories draw on assumptions of organizational action [92]. The central assumptions of behavioral theories of internationalization are (1) path dependency; (2) goal complexity; (3) contextual contingency; and (4) weak rationality requirements [84]. A behavioral perspective of internationalization has provided a fertile ground for research in the field, as it encompasses a novel and interesting perspective on understanding internationalization. Major theoretical approaches within this perspective include: (1) foreign investment decision process; (2) Uppsala model of internationalization; (3) innovation adoption 
models; (4) network approach of internationalization; (5) the evolutionary theory; (6) process theory of internationalization; (7) new venture/born global firms' theory of internationalization; (8) strategic choice theory; and (9) adaptive choice model.

In the light of the review of the internationalization theories, key assumptions, implications of assumptions of each theory, and factors specified and used in existing entrepreneurial research were summarized, as shown in Table 2. Moreover, based on the review findings, some associated key factors were derived that might influence the internationalization of women-owned SMEs. 
Table 2. Summary of the review of internationalization theories and derived factors.

\begin{tabular}{|c|c|c|c|c|c|}
\hline \multirow{2}{*}{ Theories } & \multirow{2}{*}{ Key Assumptions } & \multicolumn{2}{|c|}{ Evidence from Literature } & \multirow{2}{*}{ Implications } & \multirow{2}{*}{ Derived Factors } \\
\hline & & Contributors & Specified Factors & & \\
\hline \multicolumn{6}{|c|}{ Economic View of Internationalization } \\
\hline Product Life Cycle Theory & $\begin{array}{l}\text { The life cycle of the firm's products is } \\
\text { linked to internationalization. }\end{array}$ & Vernon [93] & Product's life cycle stage & $\begin{array}{l}\text { Businesses are compelled to } \\
\text { internationalize in order to } \\
\text { protect their existing markets } \\
\text { for mature products. }\end{array}$ & $\begin{array}{l}\text { Nature of product } \\
\text { Stage in the life cycle }\end{array}$ \\
\hline $\begin{array}{l}\text { The Monopolistic Advantage } \\
\text { Theory }\end{array}$ & $\begin{array}{l}\text { Highlights the role of the individual firm } \\
\text { as the main determinant of international } \\
\text { flows of goods and capital. }\end{array}$ & Hymer [94] & Firm-specific advantage & $\begin{array}{l}\text { To maximize profits that firms } \\
\text { exploit for their superior or } \\
\text { monopolistic advantage. }\end{array}$ & $\begin{array}{l}\text { Firm's competitive advantage } \\
\text { Product's superior value }\end{array}$ \\
\hline Internalization Theory & Firms internationalize to reduce costs. & Buckley and Casson [95] & $\begin{array}{l}\text { Intermediate products } \\
\text { (e.g., knowledge, parts, } \\
\text { and raw materials) }\end{array}$ & $\begin{array}{l}\text { Firms are internationalizing as } \\
\text { a supplier of intermediate } \\
\text { products. }\end{array}$ & $\begin{array}{l}\text { Cost reduction } \\
\text { Opportunity to be intermediate } \\
\text { suppliers }\end{array}$ \\
\hline $\begin{array}{l}\text { The Eclectic Theory of } \\
\text { Internationalization }\end{array}$ & $\begin{array}{l}\text { Firms internationalize due to ownership } \\
\text { (O) advantages, location (L) advantages, } \\
\text { and internalization (I) advantages. } \\
\text { International production will take place } \\
\text { when all three sets of advantages (OLI) } \\
\text { can be realized. }\end{array}$ & Dunning [96] & $\begin{array}{l}\text { Location-specific factors } \\
\text { (labor costs, barriers to } \\
\text { trade, and transport costs) } \\
\text { Firm's competitive } \\
\text { advantage } \\
\text { Core competence }\end{array}$ & $\begin{array}{l}\text { Location-specific factors, such } \\
\text { as labor costs, barriers to trade, } \\
\text { and transport costs, can drive } \\
\text { firms' internationalization. }\end{array}$ & $\begin{array}{l}\text { Labor costs } \\
\text { Barriers to trade } \\
\text { Transport costs } \\
\text { Product's heritage value }\end{array}$ \\
\hline \multicolumn{6}{|c|}{ Resource-Based View of Internationalization } \\
\hline Resource-Advantage Theory & $\begin{array}{l}\text { Assume that the internal resources of a } \\
\text { firm influence the internationalization of } \\
\text { small businesses. }\end{array}$ & Barney [90] & $\begin{array}{l}\text { Tangible and intangible } \\
\text { resources }\end{array}$ & $\begin{array}{l}\text { Firms' reputation, territorial } \\
\text { location, social networking as } \\
\text { resources influence the } \\
\text { internationalization process. }\end{array}$ & $\begin{array}{l}\text { Firm's performance } \\
\text { Firm's territorial location }\end{array}$ \\
\hline Competency-Based Theory & $\begin{array}{l}\text { Foreign investment decisions are heavily } \\
\text { influenced by the unique managerial } \\
\text { competencies of entrepreneurs. }\end{array}$ & Collis [97] & Managerial competencies & $\begin{array}{l}\text { Increases competitive } \\
\text { advantage }\end{array}$ & $\begin{array}{l}\text { Managerial competencies } \\
\text { Management know-how }\end{array}$ \\
\hline Human Capital Theory & $\begin{array}{l}\text { The ability to be an exporter may not be } \\
\text { solely related to the age or size of the } \\
\text { business; it is also the human capital of an } \\
\text { entrepreneur. } \\
\text { Entrepreneur's international business } \\
\text { skills, international orientation, } \\
\text { environmental perceptions, and } \\
\text { management know-how are considered } \\
\text { part of this human capital. }\end{array}$ & $\begin{array}{l}\text { Kalleberg and Leicht [98]; } \\
\text { Gimeno et al. [99]; } \\
\text { Bates [100]; } \\
\text { Westhead [101]; } \\
\text { Ruzzier et al. [102] }\end{array}$ & Human capital & $\begin{array}{l}\text { An entrepreneur is crucial } \\
\text { because the internationalization } \\
\text { process is centered on the key } \\
\text { person, her knowledge, } \\
\text { experience, and network } \\
\text { relationships. }\end{array}$ & $\begin{array}{l}\text { Entrepreneur's international } \\
\text { business skills } \\
\text { Entrepreneur's international } \\
\text { orientation } \\
\text { Entrepreneur's environmental } \\
\text { perceptions } \\
\text { Entrepreneur's management } \\
\text { know-how }\end{array}$ \\
\hline
\end{tabular}


Table 2. Cont.

\begin{tabular}{|c|c|c|c|c|c|}
\hline \multirow{2}{*}{ Theories } & \multirow{2}{*}{ Key Assumptions } & \multicolumn{2}{|c|}{ Evidence from Literature } & \multirow{2}{*}{ Implications } & \multirow{2}{*}{ Derived Factors } \\
\hline & & Contributors & Specified Factors & & \\
\hline \multicolumn{6}{|c|}{ Behavioral View of Internationalization } \\
\hline $\begin{array}{l}\text { The Foreign Investment } \\
\text { Decision Process }\end{array}$ & $\begin{array}{l}\text { Assume that decisions regarding foreign } \\
\text { investments encompass a behavioral } \\
\text { process triggered by a stimulus to invest. }\end{array}$ & Aharoni [103] & $\begin{array}{l}\text { Stimuli to foreign } \\
\text { investment }\end{array}$ & $\begin{array}{l}\text { Owners/managers' } \\
\text { commitment to investment to } \\
\text { projects depends on the time } \\
\text { and effort that they need to put } \\
\text { into these projects. }\end{array}$ & Time and effort pressure \\
\hline $\begin{array}{l}\text { Uppsala/Stage Model of } \\
\text { Internationalization }\end{array}$ & $\begin{array}{l}\text { Firms gradually increase their } \\
\text { international operations in different stages } \\
\text { as they develop knowledge, experience, } \\
\text { and relationships with international } \\
\text { markets. } \\
\text { Small firms gain experiential knowledge } \\
\text { in stages as they first enter international } \\
\text { markets with a psychic distance to gain } \\
\text { experience gradually to avoid risks. }\end{array}$ & $\begin{array}{l}\text { Johanson and Vahlne [104] } \\
\text { Hymer [95]; } \\
\text { Ruzzier et al. [102]; } \\
\text { Johanson and Vahlne [105] }\end{array}$ & $\begin{array}{l}\text { Firm's market knowledge } \\
\text { Decision-maker's market } \\
\text { knowledge }\end{array}$ & $\begin{array}{l}\text { Acts as a driving force of } \\
\text { internationalization. } \\
\text { Considered as a key factor, } \\
\text { explaining the gradual } \\
\text { internationalization process of } \\
\text { small firms. }\end{array}$ & $\begin{array}{l}\text { Foreign market knowledge } \\
\text { Past experience } \\
\text { Relationships with foreign partners } \\
\text { Foreign language }\end{array}$ \\
\hline I-Model & $\begin{array}{l}\text { Firms start involvement in international } \\
\text { trade to the countries having } \\
\text { psychologically distinct features. } \\
\text { Export activities vary for small firms } \\
\text { depending on the decision-makers of the } \\
\text { firm. } \\
\text { The process of decision-making is the key } \\
\text { to the process of internationalization. }\end{array}$ & $\begin{array}{l}\text { Bilkey and Tesar [106] } \\
\text { Reid [107] } \\
\text { Czinkota [108] }\end{array}$ & $\begin{array}{l}\text { Psychological differences } \\
\text { Role of the decision-maker } \\
\text { Decision-making process }\end{array}$ & $\begin{array}{l}\text { Each subsequent stage of } \\
\text { internationalization is } \\
\text { considered as an innovation for } \\
\text { the firm, and individual } \\
\text { learning and top managers' } \\
\text { behavior in understanding how } \\
\text { a firm behaves affects its } \\
\text { international involvement. }\end{array}$ & $\begin{array}{l}\text { Past or present experience } \\
\text { Exploration for market knowledge } \\
\text { Previous experience and reputation } \\
\text { (entrepreneur's identity), } \\
\text { founders learning, and positive } \\
\text { behavior }\end{array}$ \\
\hline $\begin{array}{l}\text { Network Theory of } \\
\text { Internationalization }\end{array}$ & $\begin{array}{l}\text { Emphasize personal relationships as the } \\
\text { key factor to enter into the international } \\
\text { market than on the political, economic, or } \\
\text { cultural conditions of the target market. }\end{array}$ & $\begin{array}{l}\text { Johanson and Mattsson }[109,110] \\
\text { Coviello and Munro [111] } \\
\text { Laforet and Tann [112] }\end{array}$ & $\begin{array}{l}\text { Network and transaction } \\
\text { costs } \\
\text { Network and firm's } \\
\text { strategy } \\
\text { Networking and poor } \\
\text { learning } \\
\text { Personal networking }\end{array}$ & $\begin{array}{l}\text { Can be constraints to becoming } \\
\text { an innovative firm and } \\
\text { consequently on } \\
\text { internationalization } \\
\text { Helps to develop knowledge of } \\
\text { the foreign market } \\
\text { opportunities, as well as initial } \\
\text { export inquiry or orders. } \\
\text { Help to reduce the cost of } \\
\text { production or transaction, and } \\
\text { contribute to knowledge } \\
\text { development and } \\
\text { competitiveness building. }\end{array}$ & Personal networking \\
\hline
\end{tabular}


Table 2. Cont.

\begin{tabular}{|c|c|c|c|c|c|}
\hline \multirow{2}{*}{ Theories } & \multirow{2}{*}{ Key Assumptions } & \multicolumn{2}{|c|}{ Evidence from Literature } & \multirow{2}{*}{ Implications } & \multirow{2}{*}{ Derived Factors } \\
\hline & & Contributors & Specified Factors & & \\
\hline $\begin{array}{l}\text { The Evolutionary Approach } \\
\text { of Internationalization }\end{array}$ & $\begin{array}{l}\text { Internationalization is dependent on and } \\
\text { contingent on the nature of knowledge. } \\
\text { The quality and nature of knowledge } \\
\text { developed by an organization and its } \\
\text { deployment are dependent on the } \\
\text { institutional settings and social } \\
\text { communities where the firm is located. }\end{array}$ & $\begin{array}{l}\text { Nelson and Winter [113]; } \\
\text { Kogut and Zander [114] }\end{array}$ & $\begin{array}{l}\text { Nature of knowledge and } \\
\text { internationalization }\end{array}$ & $\begin{array}{l}\text { The appropriate mode of an } \\
\text { international operation, i.e., } \\
\text { trade (export, licensing) and/or } \\
\text { investment (foreign direct } \\
\text { investment-FDI), is } \\
\text { determined by the nature or } \\
\text { quality of the knowledge. }\end{array}$ & Quality of knowledge \\
\hline $\begin{array}{l}\text { Process Theory of } \\
\text { Internationalization }\end{array}$ & $\begin{array}{l}\text { The internationalization process of a firm } \\
\text { is initiated in a reactive mode in response } \\
\text { to unsolicited export orders. } \\
\text { Spontaneous international orders provide } \\
\text { entrepreneurs to accumulate knowledge } \\
\text { of internationalization and learn both } \\
\text { their organization's capabilities as well as } \\
\text { international market needs. }\end{array}$ & Cyert and March [93] & Experiential knowledge & $\begin{array}{l}\text { Knowledge can be accumulated } \\
\text { from international experience. }\end{array}$ & $\begin{array}{l}\text { International orders } \\
\text { Experience of international } \\
\text { transactions } \\
\text { Firm's perception }\end{array}$ \\
\hline $\begin{array}{l}\text { New Venture/ Born Global } \\
\text { Firms' Theory of } \\
\text { Internationalization }\end{array}$ & $\begin{array}{l}\text { Early accumulation of experiential } \\
\text { knowledge facilitates early } \\
\text { internationalization. } \\
\text { Firms focus on niche markets and global } \\
\text { networks and are oriented towards } \\
\text { developing mutually beneficial } \\
\text { relationships with international partners. }\end{array}$ & $\begin{array}{l}\text { McDougall et al. [115]; } \\
\text { Oviatt and McDougall [116] } \\
\text { Bell et al. [117]; } \\
\text { Wenchen and Meizi [118] }\end{array}$ & $\begin{array}{l}\text { Ownership and } \\
\text { management issues } \\
\text { Role of } \\
\text { founder/entrepreneur }\end{array}$ & $\begin{array}{l}\text { Strongly influenced business } \\
\text { strategies and international } \\
\text { focus. } \\
\text { The founder has a tremendous } \\
\text { influence on } \\
\text { internationalization. }\end{array}$ & $\begin{array}{l}\text { Experiential knowledge } \\
\text { Role of founder/entrepreneur }\end{array}$ \\
\hline Strategic Choice Theory & $\begin{array}{l}\text { Firms evaluate the risks in changing } \\
\text { market opportunities and respond } \\
\text { strategically to internationalization efforts. } \\
\text { Internationalization is a strategic } \\
\text { management process that is related to } \\
\text { knowledge, skills, experience, network, } \\
\text { and so on }\end{array}$ & Shuman and Seeger [119] & $\begin{array}{l}\text { Vision, capabilities, and } \\
\text { prior international } \\
\text { experience } \\
\text { Strategic planning and } \\
\text { role of founder }\end{array}$ & $\begin{array}{l}\text { Has a positive effect on } \\
\text { internationalization. } \\
\text { Founder's knowledge intensity } \\
\text { has a direct influence on the } \\
\text { international business. }\end{array}$ & $\begin{array}{l}\text { Vision } \\
\text { Knowledge, skills, experience }\end{array}$ \\
\hline Adaptive Choice Model & $\begin{array}{l}\text { Internationalization is an adaptive } \\
\text { response to another challenging } \\
\text { environment, imposing on organizations. }\end{array}$ & $\begin{array}{l}\text { Lam and White [120]; } \\
\text { Havnes and Sennesseth [121] }\end{array}$ & $\begin{array}{l}\text { Environmental change as } \\
\text { an opportunity }\end{array}$ & $\begin{array}{l}\text { Unrelated changes (for } \\
\text { example, competitors move, } \\
\text { declining local demand, or } \\
\text { industry change) influence } \\
\text { internationalization decisions. }\end{array}$ & $\begin{array}{l}\text { Declining local demand } \\
\text { Increase demand in foreign markets } \\
\text { Risk of adapting to change }\end{array}$ \\
\hline
\end{tabular}




\section{Understanding Feminists' View about Women's Position in the Society: Revisiting Feminism Theories}

Why bringing feminists' views into a women entrepreneurship research is important? Ahl [35] and Ahl and Marlow [1] signified that incorporating feminist theories is essential in exploring the grass-route of different patterns of challenges women face as entrepreneurs. For example, stereotyping beliefs about gender norms (addressed in the liberal feminism theory) create numerous barriers for women business owners [70,71], even though legal, political, and economic systems provide the same rights and benefits to both men and women. Therefore, the absence of employing feminist theories as an analytical framework limits the scope of contemporary research on female entrepreneurs by highlighting women as failed and reluctant entrepreneurial subjects [1]. Bruni et al. [122] suggested that entrepreneurial research should include gender theories to assess gender and entrepreneurship as culturally produced and reproduced in social practices. Additionally, an analytical framework that includes theories from multiple areas helps to extend research implications [123].

Over time, different strands of feminist theories have unfolded, each with slight changes in perspective. For example, while Marxist feminism blamed capitalism as the root of women's subordination [124], the Africana feminism regards feminist theories as mainly focused on issues faced by women in developed countries, without considering women in less developed economies [125]. Although there are many variations within feminist theories, the tenets of the liberal and social feminist theories provide a useful dichotomy through which to consider the findings of previous research [126]. Accordingly, these two theories were revisited to understand how they could provide a conceptual lens through which the effect of gender on internationalization arises, as this study focused upon the women-led SME internationalization. Besides these two strands of feminism, the feminist standpoint theory was also revisited. The feminist standpoint theory provides insights into women's multiple roles and their impact on business [127,128].

Feminist theories incorporated in this study were based on an extensive literature review. We gave priority to the feminist theories and feminist perspective commonly addressed by researchers in prescribing a necessity to bring a feminist perspective to women entrepreneurship [129-140]. Feminist theories included in this study were those advocated by mainstream feminist theorists. Given that this study focused on women entrepreneurs' participation in international trade, irrespective of the economic status of the country, we focused more on mainstream feminist theories rather than on postcolonial feminism or third world feminism. Moreover, postcolonial feminism and third world feminism are sometimes criticized on the grounds that they weaken a wider feminist perspective by dividing it (Bulbeck) [141]. Therefore, a feminist viewpoint should move towards worldwide feminism, rather than focusing on the division between western feminism and postcolonial feminism.

Keeping this in mind, the following theories related to feminism were revisited, as shown in Table 3. Key assumptions, implications of assumptions of each theory, and evidence of application in existing entrepreneurial research are summarized in Table 3. 
Table 3. Summary of review of feminism theories and derived factors.

\begin{tabular}{|c|c|c|c|c|c|}
\hline \multirow{2}{*}{ Theories } & \multirow{2}{*}{ Key Assumptions } & \multicolumn{3}{|c|}{ Evidence from Literature } & \multirow{2}{*}{ Derived Factors } \\
\hline & & Contributors & Identified Factors & Implications & \\
\hline Liberal Feminist Theory & $\begin{array}{l}\text { 1. Society discriminates against women in } \\
\text { the academy, the forum, and the marketplace } \\
\text { as it perceives that women are, by nature, } \\
\text { less intellectually and physically capable } \\
\text { than men. } \\
\text { 2. A set of customary and legal constraints } \\
\text { that blocks women's entrance and success in } \\
\text { the so-called public world. }\end{array}$ & $\begin{array}{l}\text { Rosemarie [129]; } \\
\text { Fischer et al. [130]; } \\
\text { Unger and Crawford [131]; } \\
\text { Cliff [132]; } \\
\text { Butler [133]; } \\
\text { Greer et al. [134]; } \\
\text { Brindley [135]; } \\
\text { Morris et al. [28]; } \\
\text { De Tienne and Chandler [136]; } \\
\text { Kearney [126]; } \\
\text { Ali and Rana [21] }\end{array}$ & $\begin{array}{l}\text { Systematic biases for } \\
\text { women. For example, } \\
\text { restricted access to } \\
\text { resources, education, } \\
\text { business experience } \\
\text { Lack of relevant } \\
\text { experience }\end{array}$ & $\begin{array}{l}\text { If women had equal access to the } \\
\text { opportunities available to men, they } \\
\text { would behave similarly. } \\
\text { Lack of relevant experience affects the } \\
\text { ability to manage quickly growing } \\
\text { enterprises and, therefore, they purposely } \\
\text { limit the expansion of their firms. }\end{array}$ & $\begin{array}{l}\text { Legal constraints/ } \\
\text { customary constraints } \\
\text { Access to resources } \\
\text { Society's perception }\end{array}$ \\
\hline Social Feminist Theory & $\begin{array}{l}\text { Deliberate socialization methods create } \\
\text { differences between male and female } \\
\text { experiences from the earliest moments of life } \\
\text { that influence their way of viewing the } \\
\text { world. }\end{array}$ & $\begin{array}{l}\text { Lee-Gosselin and Grise [137]; } \\
\text { Kalleberg and Leicht [98]; } \\
\text { Fischer et al. [130]; } \\
\text { Cliff [132]; } \\
\text { Watson [138]; } \\
\text { Carter and Williams [139]; } \\
\text { DeTienne and Chandler [136]; } \\
\text { Kennedy [140]; } \\
\text { Muntean and Ozkazanc-Pan [34]; } \\
\text { Ali and Rana [21] }\end{array}$ & Socialization methods & $\begin{array}{l}\text { Socialization process influences viewing } \\
\text { the world that indirectly affects the choice } \\
\text { of business by weighing the social risk } \\
\text { and reward. }\end{array}$ & $\begin{array}{l}\text { Socialization methods } \\
\text { Perception of associate } \\
\text { risk }\end{array}$ \\
\hline $\begin{array}{l}\text { Feminist Standpoint } \\
\text { Theory }\end{array}$ & $\begin{array}{l}\text { 1. Individuals simultaneously occupy } \\
\text { multiple overlapping and interacting } \\
\text { standpoints. } \\
\text { 2. Diversity of social position and } \\
\text { intersection of everyday practices of } \\
\text { exercising power provides epistemic benefits } \\
\text { to women in the case of knowledge } \\
\text { generation. }\end{array}$ & $\begin{array}{l}\text { Chasserio et al. [127] } \\
\text { Ollila and Middleton [142] } \\
\text { Powell and Baker [143] } \\
\text { Intemann [144] } \\
\text { Intemann [144]; } \\
\text { Tuin [145] }\end{array}$ & $\begin{array}{l}\text { Private social identities } \\
\text { and public social } \\
\text { Multiple identities } \\
\text { Multiple identities } \\
\text { Diverse social positions } \\
\text { "Insiders-outsiders" } \\
\text { experience }\end{array}$ & $\begin{array}{l}\text { Female entrepreneurs' success can either } \\
\text { be hindered or enhanced by the } \\
\text { interactions of multiple identities. } \\
\text { Sometimes leads to legitimacy challenges. } \\
\text { Multiple identities may constrain } \\
\text { behaviors and actions. } \\
\text { Diverse social positions have implications } \\
\text { on the plausibility of background } \\
\text { assumptions, models, and methods. } \\
\text { Develop a unique position that helps } \\
\text { them to identify limitations or problems } \\
\text { with background assumptions. }\end{array}$ & $\begin{array}{l}\text { Multiple roles/identities } \\
\text { Responsibility to family }\end{array}$ \\
\hline
\end{tabular}


Based on the above review, it can be concluded that each theory describes women's positions in society from a different perspective. Hence, if we considered one or two of the theories separately or in conjunction, it would not provide a complete understanding of a woman's story as a business owner. For example, liberal feminists believe that men and women are essentially the same; it is the society that believes women are less intellectually and physically capable than men and are discriminated based on this belief. In contrast, social feminists believe that men and women are different due to their socialization process. In addition, standpoint feminists believe that a disadvantaged position in society gives women advantage by everyday practices of exercising power and producing knowledge to handle multiple tasks simultaneously. To sum up, these feminist theories are not mutually exclusive [126], and bringing together their insights may provide a more comprehensive explanation than a single theory can offer.

\section{Selection of Parameters and Spotlights from Entrepreneurship Perspective}

Based on the literature review of entrepreneurship and internationalization theories, we could identify factors that are required for successful entrepreneurship and internationalization activities. Some factors are addressed in both entrepreneurship and internationalization theories, such as knowledge, which is a critical element for both activities. Therefore, we termed this factor as foreign market knowledge. Some of the factors (marked in italics in Figure 2) that facilitate internationalization, such as the nature of the product, stage in the product life cycle, a product's superior value, and the product's heritage value, were not included in the set of selected factors as a gender influence was absent. Figure 2 shows factors derived from entrepreneurship theories and internationalization theories and a set of selected parameters.

Some significant molding issues (shown in Figure 2) were identified from the review of feminist theories, which have a greater influence on gender differences in society and could play a significant role in shaping the parameters selected for scrutinizing the internationalization of women-owned firms. Selected parameters were evaluated in the light of their importance for internationalization and how a woman's position in society influences these parameters. Further evidence from the existing literature was shown regarding how these parameters affect the performance of women-owned firms. Here, we discussed selected parameters that have been derived from theories that could influence international women entrepreneurship by using a gender perspective. As internationalization requires a combination of entrepreneurship, a firm, as well as the environment [146], our arguments were centered on an entrepreneur (a founder of the firm), in particular on how an entrepreneur is influenced by the environment (society) and how she affects a firm's internationalization.

International business opportunity identification is key for the development of a new business, as well as for identifying new business opportunities in foreign markets [147]. Though this factor is highlighted both in entrepreneurship and internationalization theories, any discussion from a gender perspective has been overlooked in both theories. Therefore, it is important to include this parameter in proposing a new approach to international women entrepreneurship. We focused on how international opportunity identification could be re-conceptualized by spotlighting from a gender perspective. Ellis [148] argued that firms' growth and international expansion depend on firms' ability to identify and exploit new international business opportunities.

Bringing the feminists perspective on all variables moderating opportunity identification could help us in understanding why men report a higher score in case of opportunity evaluation than women. For example, according to liberal feminism, systematic biases towards women restrict them from getting equal access to resources, education, and business experience $[21,28,126,129,130,132,135,136]$. This unequal access to such resources limits women's human capital. On the other hand, with regards to social feminists, socialization processes influence viewing the world that indirectly affects the choice of business by weighing a social risk and reward [21,22,34,98,137,138]. Other variables moderating differences in opportunity identification, such as social capital, social network, and stereotypical assumptions, are related to a social identity of women as addressed by the social 
identity theory. For instance, membership to a group may positively or negatively contribute to an individual's self-image.

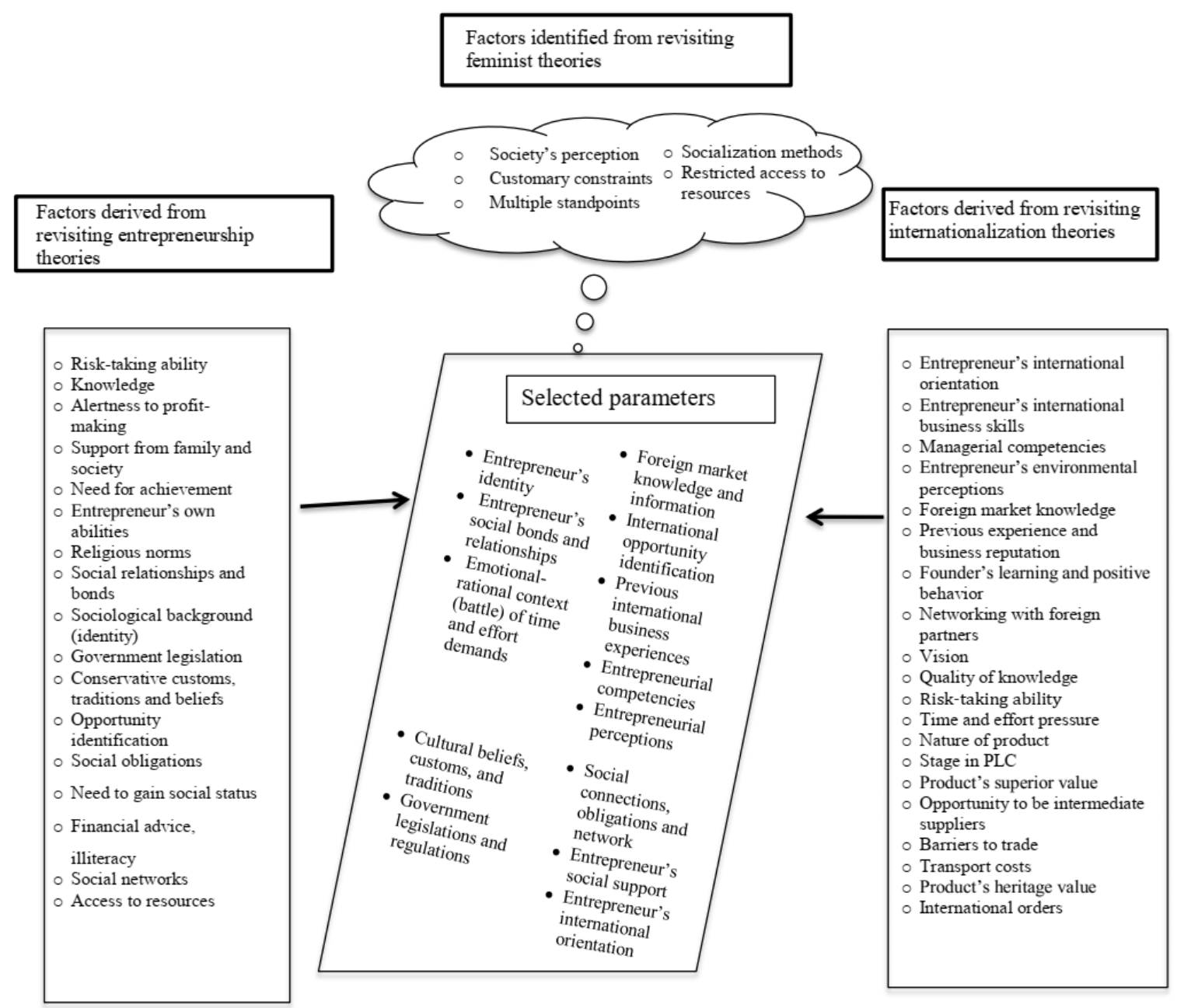

Figure 2. Selection of parameters

Women are in a disadvantageous position in obtaining foreign market knowledge and information. Musteen, Datta, and Butts [149] stressed that in case of internationalization, acquiring foreign market knowledge via international networking is necessary to overcome two severe barriers (i.e., the liability of foreignness and newness) to international expansion. Further, such knowledge improves owners' confidence that helps in managing a risk related to internationalization [150]. However, female entrepreneurs do not engage in international networks like men [151,152]. For example, women's responsibility to family $[10,151-153]$ and the lack of support from the society and family [154-156] may deter them from reaping the benefits of participating in international trade. In a recent study, García-Palma and Molina [157] argued that the construction of knowledge is connected to social processes and social structures that affect women's knowledge building and learning processes. They also referred that in both dimensions of knowledge (i.e., theoretical and practical), such social processes and structures make the difference between genders. Hence, in our theoretical perspective, we proposed to consider women's stand on acquiring foreign market knowledge for evaluating their performance as international entrepreneurs.

Entrepreneurs can gain international experience by being directly involved in business with foreign markets [158] or by expending networks with foreign partners [159]. In both approaches of gaining international experience, women entrepreneurs face challenges in the male dominant society. In addition to systematic biases (e.g., restricted access to education and resources) pointed by the liberal 
feminist theory, the feminist standpoint theory can be helpful in explaining why women entrepreneurs face more challenges compared to men entrepreneurs. As explained earlier, women entrepreneurs have to resume multiple responsibilities, and consequently, they cannot manage extra time to broaden networks with foreign partners and gain experience.

In addition, they need to behave according to social expectations $[127,142]$ due to their social identity, as explained in the social identity theory. For example, in many societies, women are allowed to work outside of home only until sunset, so in such a society, they cannot do any entrepreneurial activities after sunset. In the context of developing country culture, they need to get permission from a husband and other family members to travel abroad and visit a foreign market. Existing studies in the context of female entrepreneurship, gender, and trade have also identified an absence of international exposure as an obstacle [160-162] and a presence of international experience as a driver $[4,151]$ of the international expansion of women-owned firms. However, this issue has been explored to a limited extent and requires further investigation. Therefore, in evaluating international women entrepreneurship, we proposed to incorporate this issue as a parameter that needs to be investigated from feminists' perspectives.

Mitchelmore and Rowley [163] identified four categories of entrepreneurial competencies and argued that men and women entrepreneurs vary over the four categories of competencies-idea generation, innovative skills, envisioning opportunities, and risk-taking and creativity possessed by entrepreneurs. Carter and Shaw [164] suggested that these variations in entrepreneurial competencies might be associated with women's background, experiences, access to entrepreneurial capitals, and the socio-economic and the cultural settings where their businesses operate. In another research, Man and Lau [165] argued that components by which an entrepreneur can gain competencies are deeply connected to his/her background, i.e., traits, personality, attitudes, self-image, social roles, and training and education. Social feminists argue that the socialization process affects women's personality, attitudes, and self-image, which later affect their behavior in business activities, while liberal feminists argue that the lack of training and education makes women disadvantaged in society.

Entrepreneurial perceptions, particularly about risks, competency, and the environment, affect entrepreneurs' behavior and actions with regards to decision-making for business development and growth in both domestic and international markets [166-168]. This may act as a stumbling block, depending on the perception of negative or positive consequences. For example, Achtenhagen [169] argued that many firms do not attempt to involve in internationalization just because of their perception that they are not competent to do so.

Concerning the perception of risks and barriers, men and women entrepreneurs differ noticeably [168,170-173]. For example, regarding the perception about competency, women entrepreneurs have a tendency to regard themselves as less competent in terms of personal performance, skills, and knowledge compared to men [174]; this further influences their opportunity exploitation [175]. In the case of their business environment, women entrepreneurs are perceived as less favorable compared to their male counterparts [176]. For example, women entrepreneurs in a developed country, such as the United States, are reluctant to apply for a loan because they perceive they will be rejected, although the outcome is more likely be the same as for men [177]. Perception of the risk-taking ability, a lack of confidence, and a fear of failure have been identified as obstacles to the growth of women entrepreneurship [152,155,178-184].

Therefore, in proposing a new approach to international women entrepreneurship, we proposed to incorporate feminists' views in revealing the roots of differences in entrepreneurial perceptions. For instance, if we consider a self-perception [175] as a moderating variable of the entrepreneurial perception, a social feminist view would better explain the causes of differences in self-perception. Social feminists argue that an individual's self-perception results from the socialization process, which, in turn, shapes their way of perceiving the world $[21,22,34,136,137,139,140]$. Other two sets of factors that also affect entrepreneurial perceptions - the situational context (e.g., economy, culture) and the personal context of entrepreneurs (e.g., experience, dependents, income)—may be explained by the 
liberal feminist theory and the social identity theory. For example, Shinnar, Giacomin, and Janssen [168] identified significant gender differences in entrepreneurial perceptions and argued that the differences might vary across cultures. If we evaluate these findings by considering a different extent of practices of gender dominance (gender identity) and gender-bias (the concept from liberal feminism) across cultures, it would clarify how entrepreneur's identity and systematic biases in the society affect women entrepreneurs' perceptual process.

Furthermore, other variables identified from the entrepreneurship and internationalization theories should be analyzed from the feminist perspective to evaluate the status of success or failure of women-owned firms in international business. For instance, the nature of women's social bonds and relational attachment to childcare concerns [185], and the "couple-level strategies" [186] might affect women entrepreneurs' decision to get involved in international entrepreneurship, as such activities sometimes require women to be detached from children and family when fulfilling business requirements. Another variable of the emotional-rational context (battle) of time and effort demands should be investigated by bringing a feminist perspective into it. Emotional responses to the work-family conflict/work-family interface (WFC/WFI) vary between genders [187-189]. MacDermid et al. [190] argued that the role of emotion elicited from WFC on an individual's behavior would be better understood by bringing gender into the work-family conflict issue. Morgan and King [191] found that if an individual faces work-to-family guilt, she reduces her work responsibility, whereby a gender-role orientation plays a moderating role in such responses.

What are the factors that place women in a disadvantaged position in both the emotional and rational (positive-negative) outcome of the WFC/WFI? Nasurdin, Ahmad, and Zainal [192] argued that the internalization of the gender role ideology creates differences in both work-family conflict and work-family facilitation between men and women. Besides, studies found no significant gender differences in the WFC, but they outlined that such findings might be due to changes in culture by inserting new values concerning work-family responsibilities [192,193]. The findings of these studies revealed that what conflict an individual faces in the WFC and how he responds to them largely depends on social-cultural values. For example, the internalization of the gender role ideology suggests differences in facilitation between men and women. Incorporating feminist concepts from both liberal and social feminisms would be helpful in explaining how changes in social values can change the phenomena.

Hence, we argued that a theoretical perspective should consider all the identified parameters from entrepreneurship and internationalization theories in evaluating international women entrepreneurs. Otherwise, it would provide misleading findings on women entrepreneurs' competency in international business that, in turn, influence women entrepreneurs' perception of advancing their international business.

\section{Conclusions}

This study revisited feminism, entrepreneurship, and internationalization foundations to examine the factors affecting women-owned SMEs' entry in foreign markets. To identify the factors that facilitate success or failure in entrepreneurship and internationalization, this study explored theories related to both entrepreneurship and internationalization domains. Furthermore, feminist theories were revisited to identify the issues that influence those factors that are relevant for a successful international women entrepreneurship.

The overview of entrepreneurship and internationalization theories revealed that theories in both domains overlook the viewpoint of feminist theories. Given that the number of women entrepreneurs is increasing at an accelerating rate and several initiatives are implemented to bring women to the international business platform, incorporating feminist views in the international entrepreneurship theory is an important task. As no single theory of entrepreneurship or internationalization describes female entrepreneurship, especially international female entrepreneurship, in this study, we used the feminist viewpoints for this purpose. Based on the review of theories related to entrepreneurship 
and internationalization, a set of factors was selected. The revisiting of theories revealed that issues addressed in feminist theories, directly and indirectly, influence the factors highlighted in entrepreneurship and internationalization theories. This study pointed out how issues addressed in feminist theories influence the selected parameters that might affect women entrepreneurs doing or wanting to do international business. For instance, the nature of women's social bonds and relational attachment to childcare concerns [185] and the "couple-level strategies" [186] might affect women entrepreneurs' decision to be involved in international entrepreneurship, as such activities sometimes require them to be detached from children and family when fulfilling their business requirements. Another variable is the emotional-rational context (battle) of time and effort demands. Emotional responses to the work-family conflict/work-family interface (WFC/WFI) vary between genders [186,187]. MacDermid et al. [190] argued that the role of emotions elicited from the WFC on an individual's behavior would be better understood by bringing gender into the work-family conflict issue. Therefore, we suggested that the factors selected in this study should be considered from the feminist perspectives in assessing women-owned SMEs' entry in the foreign market.

\section{Practical Implications and Future Research Avenues}

The main beneficiary of this study was research scholars. The findings of this study could serve as guidance in developing a gender-aware theory of SMEs internationalization. As SME's women entrepreneurs are significant in numbers (e.g., 31\%-38\% in an emerging economy, IFC [194]), a new theory of women-owned enterprises is needed to fill in an important research gap.

The second beneficiary group of this study was women entrepreneurs. Exporting, as the form of internationalization is considered a "life-changing experience" [152], helps women to grow not only by increasing business revenue but also personally. Therefore, findings of this study would provide better insight for women SME owners, managers, as well as policymakers in determining the driving forces for participation in international trade.

In addition, the findings of this study extended the existing knowledge about women-led SMEs by identifying barriers, drivers, and impacts of internationalization. While identifying barriers to internationalization faced by SMEs (i.e., may be owned by men or women), some existing literature $[10,45]$ argued that women-owned SMEs might face more barriers compare to their counterparts. Only a few studies have been carried out to identify the barriers and drivers that influence the women-led SMEs, while, more specifically, no research has been done on women-led SMEs and internationalization challenges. Our findings filled in this gap by focusing on women entrepreneurs.

Our findings could serve as an initial step in developing a gender-aware theory on SME internationalization. The factors identified in this study were based on the commonly used theories in the three domains (i.e., feminism, entrepreneurship, and internationalization). Future research is needed to investigate the proposed factors through an empirical analysis. This study mainly focused on identifying the factors significantly affecting SMEs owned by women entrepreneurs. Therefore, the identified factors may yield different results in the case of large, established firms owned by women entrepreneurs. Future research is also needed to determine the domain in which the identified factors can be applied. This research is an initiative to propose a framework and later on to ground a theory that will evaluate women-owned firms involved in international trade. Therefore, future research could be conducted to develop a framework and validate it based on the factors identified in this study through qualitative or quantitative analyses.

Author Contributions: Conceptualization, M.A. and M.R.; methodology, M.A. and M.R.; validation, M.R. and D.R.; formal analysis, M.A. and M.R.; investigation, M.A.; writing-original draft preparation, M.A., M.R. and D.R.; writing一review and editing, M.A., M.R. and D.R.; visualization, M.A.; supervision, M.R. and D.R.

Funding: This research received no external funding.

Conflicts of Interest: The authors declare no conflict of interest. 


\section{References}

1. Ahl, H.; Marlow, S. Exploring the dynamics of gender, feminism and entrepreneurship: Advancing debate to escape a dead end? Organization 2012, 19, 543-562. [CrossRef]

2. Alves, M.F.R.; Galina, S.V.R.; Macini, N.; Carvalho, L.C.; Costa, T. Internationalisation and innovation in nascent companies: Does gender matter? J. Small Bus. Enterp. Dev. 2017, 24, 887-905. [CrossRef]

3. Global Entrepreneurship Monitor (GEM) Women's Entrepreneurship 2016/2017 Report. Global Entrepreneurship Monitor, 2016. Available online: www.gemconsortium.org/report/49860 (accessed on 23 March 2018).

4. Gundlach, S.; Sammartino, A. Australia's Underestimated Resource: Women Doing Business Globally; Women in Global Business and University of Melbourne: Melbourne, Australia, 2013.

5. International Labor Organization (ILO). Women's Entrepreneurship Development in Tanzania: Insights and Recommendations; ILO Publications: Geneva, Switzerland, 2014.

6. World Trade Organization (WTO). Leveling the Trading Field for SMEs; WTO Publications: Geneva, Switzerland, 2016.

7. International Trade Centre (ITC). Gender and Trade. Inter-Agency Task Force on Financing for Development, Issue Brief. 2016. Available online: http://www.un.org/esa/ffd/ffd-follow-up/inter-agency-task-force.html (accessed on 12 March 2017).

8. World Trade Organization (WTO) Gender Aware Trade Policy: A Springboard for Women's Economic Empowerment. 2017. Available online: https://www.wto.org/english/news_e/news17_e/dgra_21jun17_e.pdf (accessed on 2 January 2017).

9. International Trade Centre (ITC). SME Competitiveness Outlook 2017-The Region: A Door to Global Trade; International Trade Centre: Geneva, Switzerland, 2017. Available online: http://www.intracen.org/ SMEOutlook/ (accessed on 25 February 2017).

10. International Trade Centre (ITC). Unlocking Markets for Women to Trade. Geneva: International Trade Centre. 2015. Available online: http://www.intracen.org/uploadedFiles/intracenorg/Content/Publications/ women_in_trade_web.pdf (accessed on 31 January 2017).

11. Allen, I.E.; Elam, A.; Langowitz, N.; Dean, M. Global Entrepreneurship Monitor Report on Women and Entrepreneurship; The Centre for Women's Leadership, Babson College: Wellesley, MA, USA, 2007.

12. Bates, T. Restricted access to markets characterizes women-owned businesses. J. Bus. Ventur. 2002, 17, 313-324. [CrossRef]

13. Pearson, R. Beyond women workers: Gendering CSR. Third World Q. 2007, 28, 731-749. [CrossRef]

14. Ragodoo, N. Raising the role of Women in International Trade: A developing country's perspective. In Proceedings of the International Conference on International Trade and Investment, Moka, Mauritius, 19-21 December 2011.

15. United Nations. Gender Equality and Trade Policy; United Nations Inter-Agency Network on Women and Gender Equality (IANWGE): New York, NY, USA, 2011.

16. Weiler, S.; Bernasek, A. Dodging the glass ceiling? Networks and the new wave of female entrepreneurs. Soc. Sci. J. 2001, 38, 85-103. [CrossRef]

17. International Finance Corporation (IFC). Investing in Women: New Evidence for the Business Case; International Finance Corporation: Washington, DC, USA, 2017. Available online: https://www.ifc.org/wps/wcm/connect/topics_ext_content/ifc_external_corporate_site/gender+at+ ifc/priorities/entrepreneurship/investing+in+women_new+evidence+for+the+business+case (accessed on 27 June 2018).

18. Joshi, A.; Neely, B.; Emrich, C.; Griffiths, D.; George, G. Gender research in AMJ: An overview of five decades of empirical research and calls to action thematic issue on gender in management research. Acad. Manag. J. 2015, 58, 1459-1475. [CrossRef]

19. Burgoon, B.; Hiscox, M.J. The Gender Divide over International Trade: Why Do Men and Women Have Different Views about Openness to the World Economy? Harvard University: Cambridge, MA, USA, 2008.

20. Rice, J.S. Free trade, fair trade and gender inequality in less developed countries. Sustain. Dev. 2010, 18, 42-50. [CrossRef]

21. Ali, M.J.; Rana, M.M. Women entrepreneurship of Bangladesh: A contextual study on beauty parlor business of Rangpur expanse. Int. J. Bus. Econ. Res. 2016, 5, 61-70. 
22. Brush, C.G.; Bruin, A.; Welter, F. A gender-aware framework for women's entrepreneurship. Int. J. Gend. Entrep. 2009, 1, 8-24. [CrossRef]

23. Henry, C.; Foss, L.; Ahl, H. Gender and entrepreneurship research: A review of methodological approaches. Int. Small Bus. J. 2016, 34, 217-241. [CrossRef]

24. Patterson, N.; Mavin, S.; Turner, J. Unsettling the gender binary: Experiences of gender in entrepreneurial leadership and implications for HRD. Eur. J. Train. Dev. 2012, 36, 687-711. [CrossRef]

25. Farashah, A.D. The effects of demographic, cognitive and institutional factors on development of entrepreneurial intention: Toward a socio-cognitive model of entrepreneurial career. J. Int. Entrep. 2015, 13, 452-476. [CrossRef]

26. Buttner, E.H.; Moore, D.P. Women Entrepreneurs: Moving Beyond the Glass Ceiling, 1st ed.; SAGE Publications, Inc.: Thousand Oaks, CA, USA, 1997.

27. Bendl, R. Gender subtexts-Reproduction of exclusion in organizational discourse. Br. J. Manag. 2008, 19, S50-S64. [CrossRef]

28. Morris, H.M.; Miyasaki, N.; Watters, C.E.; Coombes, S.M. The dilemma of growth: Understanding venture size choices of women entrepreneurs. J. Small Bus. Manag. 2006, 44, 221-244. [CrossRef]

29. Meyerson, D.E.; Kolb, D.M. Moving out of the 'Armchair': Developing a framework to bridge the gap between feminist theory and practice. Organization 2000, 7, 553-571. [CrossRef]

30. Foo, M.D. Emotions and entrepreneurial opportunity evaluation. Entrep. Theory Pract. 2011, 35, 375-393. [CrossRef]

31. Shepherd, B. Trade and Gender Inclusion: What do the Data Say? Developing Trade Consultant: New York, NY, USA, 2015.

32. Elam, A.; Terjesen, S. Institutional logics. Eur. J. Dev. Res. 2010, 22, 331-348. [CrossRef]

33. Hurley, A.E. Incorporating feminist theories into sociological theories of entrepreneurship. Women Manag. Rev. 1999, 14, 54-62. [CrossRef]

34. Muntean, S.C.; Ozkazanc-Pan, B. A gender integrative conceptualization of entrepreneurship. N. Engl. J. Entrep. 2015, 18, 27-40. [CrossRef]

35. Ahl, H. Why research on women entrepreneurs needs new directions. Entrep. Theory Pract. 2006, 30, 595-621. [CrossRef]

36. Vossenberg, S. Beyond the Critique: How Feminist Perspectives Can Feed Entrepreneurship Promotion in Developing Countries; Maastricht School of Management: Maastricht, The Netherlands, 2014.

37. Wallace, J.E. Job stress, depression and work-to-family conflict: A test of the strain and buffer hypotheses. Relat. Ind. 2005, 60, 510-539.

38. Calás, M.B.; Bourne, K.A. Extending the boundaries: Reframing "entrepreneurship as social change" through feminist perspectives. Acad. Manag. Rev. 2009, 34, 552-569. [CrossRef]

39. Ely, R.J.; Meyerson, D.E. Advancing gender equity in organizations: The challenge and importance of maintaining a gender narrative. Organization 2000, 7, 589-608. [CrossRef]

40. Escribano, J.J.G.; Casado, A.B.F. Construction of gender differences in the discourse of entrepreneurship, psychobiological, cultural and familiar aspects. Suma De Neg. 2016, 7, 18-24. [CrossRef]

41. Foss, L. Research on entrepreneur networks: The case for a constructionist feminist theory perspective. Int. J. Gend. Entrep. 2010, 2, 83-102. [CrossRef]

42. Frese, M.; Gielnik, M.M. The psychology of entrepreneurship. Annu. Rev. Organ. Psychol. Organ. Behav. 2014, 1, 413-438. [CrossRef]

43. Loza, E. Female entrepreneurship theory: A multidisciplinary review of resources. J. Women Entrepreneurship Edu. Instit. Econ. Sci. (Belgrade Serbia) 2011, 26-64. Available online: https://papers.ssrn.com/sol3/papers. cfm?abstract_id=1833385 (accessed on 2 February 2017).

44. Jalbert, S.E. Women Entrepreneurs in the Global Economy. 2000. Available online: https://womenentrepreneurs-in-the-global-economy.pdf (accessed on 2 February 2017).

45. Curtis Research. Supporting Small Businesses in Developing Countries: Which Programmes Work and Why? Curtis Research, 2016. Available online: http://curtisresearch.org/publications/supporting-small-businessesin-developing-countries-which-programmes-work-and-why/ (accessed on 25 April 2018).

46. Muñoz-Bullón, F.; Sánchez-Bueno, M.J.; Antonio Vos-Saz, A. Nascent entrepreneurs' personality attributes and the international dimension of new ventures. Int. Entrep. Manag. 2015, 11, 473-492. [CrossRef] 
47. Grant, C.; Osanloo, A. Understanding, selecting, and integrating a theoretical framework in dissertation research: Creating the blueprint for your "house". Adm. Issues J. Educ. Pract. Res. 2014, 4, 12-26. [CrossRef]

48. Dubin, R. Theory Building, 2nd ed.; Free Press: New York, NY, USA, 1978.

49. Ardichvili, A.; Cardozo, R.; Ray, S. A theory of entrepreneurial opportunity identification and development. J. Bus. Ventur. 2003, 18, 105-123. [CrossRef]

50. Kirzner, I.M. Competition and Entrepreneurship; University of Chicago Press: Chicago, IL, USA, 1973.

51. Kirzner, I.M. Creativity and/or alertness: A reconsideration of the Schumpeterian entrepreneur. Rev. Austrian Econ. 1999, 11, 5-17. [CrossRef]

52. Schumpeter, J.A. The Theory of Economic Development; Harvard University Press: Cambridge, MA, USA, 1934.

53. Grebel, T.; Pyka, A.; Hanusch, H. An Evolutionary Approach to the Theory of Entrepreneurship. 2001. Available online: http://www.wiwi.uni-augsburg.de/vwl/institut/paper/206.pdf (accessed on 5 May 2018).

54. Schlutz, T.W. The value of the ability to deal with disequilibria. J. Econ. Lit. 1975, 13, 827-846.

55. Granovetter, M.S. The strength of weak ties. A network theory revisited. Sociol. Theory 1983, 1, $201-233$. [CrossRef]

56. Cantillon, R. (Ed.) Essays on the Nature of Commerce in General; Classics in Economics Series: Classics in Economics Edition; Transaction Publishers: Piscataway, NJ, USA, 2001.

57. Smith, A. An Inquiry into the Nature and Causes of the Wealth of Nations; Irwin: Homewood, IL, USA, 1776.

58. Ricardo, D. The Principles of Political Economy and Taxation; Cambridge University Press: Cambridge, UK, 1817.

59. Jevons, W.S.; Collison Black, R.D. (Eds.) The Theory of Political Economy; Penguin Books: London, UK, 1871.

60. Marshall, A. Economics of Industry; Macmillan: London, UK, 1912.

61. Hawley, F.B. Enterprise and profit. Q. J. Econ. 1900, 15, 75-105. [CrossRef]

62. Hebert, R.F.; Link, A.N. Historical perspectives on the entrepreneur. Found. Trends Entrep. 2006, 2, $261-408$. [CrossRef]

63. Rotter, J.B. Generalized expectancies for internal versus external control of reinforcement. Psychol. Monogr. Gen. Appl. 1966, 80, 1-28. [CrossRef]

64. Simpeh, K. Entrepreneurship theories and empirical research: A summary view of the literature. Eur. J. Bus. Manag. 2011, 3, 1-9.

65. McClelland, D.C. The Achieving Society; Van Nostrand: Princeton, NJ, USA, 1961.

66. Weber, M. The Protestant Ethic and the Spirit of Capitalism; George Allen and Unwin: London, UK, 1930.

67. Dana, L.P. Entrepreneurship in a remote sub-arctic community. Entrep. Theory Pract. 1995, 20, 57-72. [CrossRef]

68. Casson, M. Enterprise and Competitiveness: A Systems View of International Business; Clarendon Press: Oxford, UK, 1990.

69. Reynolds, P.D. Sociology and entrepreneurship: Concepts and contributions. Entrep. Theory Pract. 1991, 16, 47-70. [CrossRef]

70. Mitchell, R.K.; Smith, J.B.; Morse, E.A.; Seawright, K.W.; Peredo, A.; McKenzie, B. Are entrepreneurial cognitions universal? Assessing entrepreneurial cognitions across cultures. Entrep. Theory Pract. 2002, 26, 9-32. [CrossRef]

71. Baskerville, R.F. Hofstede never studied culture. Account. Organ. Soc. 2003, 28, 1-14. [CrossRef]

72. North, D.C. Institutions, Institutional Change, and Economic Performance; Norton: New York, NY, USA, 1990.

73. Shane, S.A. The effect of national culture on the choice between licensing and direct foreign investment. Strateg. Manag. J. 1994, 15, 627-642.

74. Drucker, P.F. Innovation and Entrepreneurship; Harper and Row Publishers: New York, NY, USA, 1985.

75. Stevenson, H.H.; Jarillo, J.C. A paradigm of entrepreneurship: Entrepreneurial management. Strateg. Manag. J. 1990, 11, 17-27.

76. Becker, G.S. Human Capital; Chicago University Press: Chicago, IL, USA, 1975.

77. Unger, J.M.; Rauch, A.; Frese, M.; Rosenbusch, N. Human capital and entrepreneurial success: A meta-analytical review. J. Bus. Ventur. 2011, 26, 341-358. [CrossRef]

78. Boudieu, P. The forms of capital. In Handbook of Theory and Research for the Sociology of Education; Richardson, J., Ed.; Greenwood: Westport, CT, USA, 1986; pp. 241-258.

79. Coleman, J.S. Social capital and the creation of human capital. Am. J. Sociol. 1988, 94, S95-S120. [CrossRef]

80. Putnam, R.D. The prosperous community. Am. Prospect 1993, 4, 35-42. 
81. Sarasvathy, S. Causation and effectuation: Toward a theoretical shift from economic inevitability to entrepreneurial contingency. Acad. Manag. Rev. 2001, 26, 243-263. [CrossRef]

82. Andersson, S. The internationalisation of the firm from an entrepreneurial perspective. Int. Stud. Manag. Organ. 2000, 30, 63-92.

83. Burgel, O.; Fier, A.; Licht, G.; Murray, G. The Internationalisation of Young High-Tech Firms: An Empirical Analysis in GERMANY and the United Kingdom; Springer: Heidelberg, Germany; London, UK, 2004.

84. Junior, R.E.S. Meaningful Internationalisation: A Study among the Leaders of Brazilian Smaller Enterprises. Ph.D. Thesis, The University of Birmingham, Birmingham, UK, 2011.

85. Barney, J.; Wright, M.; Ketchen, D.J. The resource based view of the firm: Ten years after 1991. J. Manag. 2001, 6, 625-641. [CrossRef]

86. Peng, M.W. The resource based view and international business. J. Manag. 2001, 27, 803-829. [CrossRef]

87. Hoskisson, R.E.; Eden, L.; Lau, C.M.; Wright, M. Strategy in emerging economies. Acad. Manag. J. 2000, 43, 249-267.

88. Kazlauskaitè, R.; Autio, E.; Gelbūda, M.; Šarapovas, T. The resource-based view and SME internationalisation: An emerging economy Perspective. Entrep. Bus. Econ. Rev. 2015, 3, 53-64. [CrossRef]

89. Barney, J. Firm resources and sustained competitive advantage. J. Manag. 1991, 17, 99-120. [CrossRef]

90. Saeedi, M.R.; Dadfar, H.; Brege, S. Rapid Internationalisation of SMEs from Resource Based View: A Longitudinal Study of a Pharmaceutical Company in Iran; Department of Industrial Marketing, Linkoping University: Linkoping, Sweden, 2012.

91. Bloodgood, J.M.; Sapienza, H.J.; Almeida, J.G. The internationalisation of new high potential U.S. ventures: Antecedents and outcomes. Entrep. Theory Pract. 1996, 20, 61-76. [CrossRef]

92. Cyert, R.M.; March, J.G. A Behavioral Theory of the Firm; Prentice-Hall: Englewood Cliffs, NJ, USA, 1963.

93. Vernon, R. International investment and international trade in the product cycle. Q. J. Econ. 1966, 80, $190-207$. [CrossRef]

94. Hymer, S.H. The International Operations of National Firms: A Study of Direct Foreign Investment; MIT Press: Cambridge, MA, USA, 1976.

95. Buckley, P.; Casson, M. The Future of the Multinational Enterprise; Palgrave Macmillan: London, UK, 1976.

96. Dunning, J.H. Explaining changing patterns of international production: In defense of the eclectic theory. Oxf. Bull. Econ. Stat. 1979, 41, 269-295. [CrossRef]

97. Collis, D.J. A resource-based analysis of global competition: The case of the bearings industry. Strateg. Manag. J. 1991, 12, 49-68. [CrossRef]

98. Kalleberg, A.; Leicht, K. Gender and organizational performance: Determinants of small business survival and success. Acad. Manag. J. 1991, 34, 136-161.

99. Gimeno, J.; Folta, T.B.; Cooper, A.C.; Woo, C.Y. Survival of the fittest? Entrepreneurial human capital and the persistence of underperforming firms. Adm. Sci. Q. 1997, 42, 750-783. [CrossRef]

100. Bates, T. Survival patterns among newcomers to franchising. J. Bus. Ventur. 1998, 13, 113-130. [CrossRef]

101. Westhead, P. Exporting and non-exporting small firms in Great Britain. Int. J. Entrep. Behav. Res. 1995, 1, 6-36. [CrossRef]

102. Ruzzier, M.; Antonic, B.; Hisrich, R.D.; Konecnik, M. Human capital and SME internationalisation: A structural equation modeling study. Can. J. Adm. Sci. 2007, 24, 15-29. [CrossRef]

103. Aharoni, Y. The Foreign Investment Decision Process; Harvard Business School: Boston, MA, USA, 1966.

104. Johanson, J.; Vahlne, J.E. The internationalisation process of the firm: A model of knowledge development and increasing foreign market commitments. J. Int. Bus. Stud. 1977, 8, 25-34. [CrossRef]

105. Johanson, J.; Vahlne, J.E. The Uppsala internationalisation process model revisited: From liability of foreignness to liability of outsidership. J. Int. Bus. Stud. 2009, 40, 1411-1431. [CrossRef]

106. Bilkey, W.J.; Tesar, G. The export behavior of smaller-sized Wisconsin manufacturing firms. J. Int. Bus. Stud. 1977, 8, 93-98. [CrossRef]

107. Reid, S.D. The decision-maker and export entry and expansion. J. Int. Bus. Stud. 1981, 12, 101-112. [CrossRef]

108. Czinkota, M.R. Export Development Strategies: US Promotion Policies; Praeger Publishers: New York, NY, USA, 1982.

109. Johanson, J.; Mattsson, L.-G. Interorganizational relations in industrial systems: A network approach compared with the transaction-cost approach. Int. Stud. Manag. Organ. 1987, 17, 34-48. [CrossRef] 
110. Johanson, J.; Mattsson, L.G. Internationalization in Industrial Systems-A Network Approach. In Strategies in Global Competition; Hood, N., Vahlne, J., Eds.; Croom Helm: New York, NY, USA, 1988.

111. Coviello, N.E.; Munro, H.J. Growing the entrepreneurial firm: Networking for international market development. Eur. J. Mark. 1995, 29, 49-61. [CrossRef]

112. Laforet, S.; Tann, J. Innovative characteristics of small manufacturing firms. J. Small Bus. Enterp. Dev. 2006, 23, 363-380. [CrossRef]

113. Nelson, R.R.; Winter, S.G. Toward an evolutionary theory of economic capabilities. Am. Econ. Rev. 1973, 63, 440-449.

114. Kogut, B.; Zander, U. Knowledge of the firm and the evolutionary theory of the multinational corporation. J. Int. Bus. Stud. 1993, 24, 625-645. [CrossRef]

115. McDougall, P.P.; Shane, S.; Oviatt, B.M. Explaining the formation of international new ventures: The limits of theories from international business research. J. Bus. Ventur. 1994, 9, 469-487. [CrossRef]

116. Oviatt, B.M.; McDougall, P.P. Toward a theory of international new ventures. J. Int. Bus. Stud. 2005, 36, 29-41. [CrossRef]

117. Bell, J.; Mcnaughton, R.; Young, S.; Crick, D. Towards an integrative model of small firm internationalization. J. Int. Entrep. 2003, 1, 339-362. [CrossRef]

118. Wenchen, L.I.; Meizi, L.I. The effect of entrepreneurship for the internationalisation of SMEs. In Proceedings of the 2nd International Forum of Business Education, Lilydale, Australia, 16-17 September 2007.

119. Shuman, J.; Seeger, J. The theory and practice of strategic management in smaller rapid growth firms. Am. J. Small Bus. 1986, 11, 7-18. [CrossRef]

120. Lam, L.W.; White, L.P. An adaptive model of the internationalisation process: Lessons drawn from the president enterprise corporation. Int. J. Organ. Anal. 1999, 7, 105-134. [CrossRef]

121. Havnes, P.A.; Sennesseth, K. A panel study of firm growth among SMEs in networks. Small Bus. Econ. 2001, 16, 293-302. [CrossRef]

122. Bruni, A.; Gherardi, S.; Poggio, B. Gender and Entrepreneurship: An Ethnographic Approach; Routledge: London, UK, 2005.

123. Thornton, P.H. The sociology of entrepreneurship. Annu. Rev. Sociol. 1999, 25, 19-46. [CrossRef]

124. Burr, V. Gender and Social Psychology; Routledge: New York, NY, USA; London, UK, 1998.

125. Giddens, A.; Griffiths, S. Sociology, 5th ed.; Polity Press: Cambridge, UK, 2006.

126. Kearney, G. The Entrepreneurial Process and the Role of Gender: A Comparative Study of Entrepreneurs in the Business Services and Technology Sectors in Scotland. 2012. Available online: http://openair.rgu.ac.uk (accessed on 22 April 2018).

127. Chasserio, S.; Pailot, P.; Poroli, C. When entrepreneurial identity meets multiple social identities. Int. J. Entrep. Behav. Res. 2014, 20, 128-154. [CrossRef]

128. Wood, G. Gender stereotypical attitudes: Past, present and future influences on women's career advancement. Equal Oppor. Int. 2008, 27, 613-628. [CrossRef]

129. Rosemarie, T. Liberal Feminism Feminist Thought: A Comprehensive Introduction; Routledge: London, UK, 1992.

130. Fischer, E.M.; Reuber, A.R.; Dyke, L.S. A theoretical overview and extension of research on sex, gender and entrepreneurship. J. Bus. Ventur. 1993, 8, 151-168. [CrossRef]

131. Unger, R.; Crawford, M. Women and Gender, A Feminist Psychology, 2nd ed.; McGraw-Hill: New York, NY, USA, 1996.

132. Cliff, J.E. Does one size fit all? Exploring the relationship between attitudes towards growth, gender. J. Bus. Ventur. 1998, 13, 523-542. [CrossRef]

133. Butler, J.E. (Ed.) New Perspectives on Women Entrepreneurs; A Volume in Research in Entrepreneurship and Management; Information Age Publishing: Greenwich, CT, USA, 2003.

134. Greer, M.; Greene, P.G.; Butler, J.E. Feminist Theory and the Study of Entrepreneurship. In New Perspectives on Women Entrepreneurs, Research in Entrepreneurship and Management; Information Age Publishing: Greenwich, CT, USA, 2003.

135. Brindley, C. Barriers to women achieving their entrepreneurial potential: Women and risk. Int. J. Entrep. Behav. Res. 2005, 11, 144-161. [CrossRef]

136. DeTienne, D.R.; Chandler, G.N. The role of gender in opportunity identification. Entrep. Theory Pract. 2007, 31, 365-386. [CrossRef] 
137. Lee-Gosselin, H.; Grise, J. Are women owner-managers challenging our entrepreneurship? J. Bus. Ethics 1990, 9, 423-433. [CrossRef]

138. Watson, J. Comparing the performance of male- and female-controlled businesses: Relating outputs to inputs. Entrep. Theory Pract. 2002, 26, 91-100. [CrossRef]

139. Carter, N.M.; Williams, M.L. (Eds.) Comparing social feminism and liberal feminism. In New Perspectives on Women Entrepreneurs; Information Age Publishing: Greenwich, CT, USA, 2003.

140. Kennedy, L.E. Socialist feminism: What difference did it make to the history of women's studies? Fem. Stud. 2008, 34, 497-525.

141. Bulbeck, C. Re-Orienting Western Feminisms: Women's Diversity in a Postcolonial World; Cambridge University Press: Cambridge, NY, USA, 1998.

142. Ollila, S.; Middleton, K.W. Entrepreneurial Identity Construction-What does existing literature tell us? In Proceedings of the Institute of Small Business and Entrepreneurship Conference, Dublin, Ireland, 7-8 November 2012.

143. Powell, E.E.; Baker, T. It's what you make of it: Founder identity and enacting strategic responses to adversity. Acad. Manag. J. 2014, 57, 1406-1433. [CrossRef]

144. Intemann, K. 25 years of feminist empiricism and standpoint theory: Where are we now? Hypatia 2010, 25, 778-796. [CrossRef]

145. Tuin, I. Feminist Standpoint Theory. In The Wiley Blackwell Encyclopedia of Gender E Sexuality Studies; Naples, N., Ed.; Wiley-Blackwell: Oxford, UK, 2016; pp. 1-4.

146. Anzengruber, J. Discovering gaps in internationalisation competences of SMEs-a comparative case study of Austrian SMEs. Bus. Manag. Stud. 2016, 1, 23.

147. Linderstrand, A.; Hånell, S.M. International and market-specific social capital effects on international opportunity exploitation in the internationalisation process. J. World Bus. 2017, 52, 653-663. [CrossRef]

148. Ellis, P.D. Social ties and international entrepreneurship: Opportunities and constraints affecting firm internationalisation. J. Int. Bus. Stud. 2011, 42, 99-127. [CrossRef]

149. Musteen, M.; Datta, D.K.; Butts, M.M. Do international networks and foreign market knowledge facilitate SME internationalisation? Evidence from the Czech Republic. Entrep. Theory Pract. 2014, 38, 749-774. [CrossRef]

150. Liesch, P.; Welch, L.; Buckley, P. Risk and uncertainty in internationalisation and international entrepreneurship studies. Manag. Int. Rev. 2011, 51, 851-873. [CrossRef]

151. Orser, B.; Riding, A.; Townsend, J. Exporting as a means of growth for women-owned Canadian SMEs. J. Small Bus. Entrep. 2004, 17, 153-174. [CrossRef]

152. Welch, C.L.; Welch, D.E.; Hewerdine, L. Gender and export behaviour: Evidence from women-owned enterprises. J. Bus. Ethics 2008, 83, 113-126. [CrossRef]

153. Rosenbaum, G.O. Female entrepreneurial networks and foreign market entry. J. Small Bus. Enterp. Dev. 2017, 24, 119-135. [CrossRef]

154. Asia-Pacific Economic Cooperation Secretariat. Women's SMEs: Conquering International Markets. SOM Steering Committee on Economic and Technical Cooperation (SCE). Policy Partnership on Women and the Economy (PPWE). 2017. Available online: https://www.apec.org/Publications/2017/05/Womens-SMEsConquering-International-Markets (accessed on 23 June 2018).

155. Faisal, M.N.; Jabeen, F.; Katsioloudes, M.I. Strategic interventions to improve women entrepreneurship in GCC countries: A relationship modeling approach. J. Entrep. Emerg. Econ. 2017, 9, 161-180. [CrossRef]

156. Scott, J.M.; Harrison, R.T.; Hussain, J.; Millman, C. The role of guanxi networks in the performance of women-led firms in China. Int. J. Gend. Entrep. 2014, 6, 68-82. [CrossRef]

157. García-Palma, M.B.; Sánchez-Mora Molina, M.I. Knowledge and female entrepreneurship: A competence and social dimension. Suma De Neg. 2016, 7, 32-37. [CrossRef]

158. Child, J.; Hsieh, L.; Elbannad, S.; Karmowska, J.; Svetla Marinova, S.; Puthusserry, P.; Tsai, T.; Narooz, R.; Zhang, Y. SME international business models: The role of context and experience. J. World Bus. 2017, 52, 664-679. [CrossRef]

159. Calabrò, A.; Campopiano, G.; Basco, R.; Pukall, T. Governance structure and internationalisation of family-controlled firms: The mediating role of international entrepreneurial orientation. Eur. Manag. J. 2017, 35, 238-248. [CrossRef] 
160. AFICS-Egypt. Towards Gender-Sensitive SME policy in Egypt. 2007. Available online: http://www.mof.gov. eg/mofgallerysource/english/sme/research_studies/31.pdf (accessed on 6 November 2019).

161. OECD. Empowering SMEs: Economic Development and the New Arab World. In Proceedings of the The Arab International Women's Forum, Sharjah, UAE, 15-17 May 2012.

162. Roomi, M.A.; Harrison, P.; Beaumont-Kerridge, J. Women-owned small and medium enterprises in England: Analysis of factors influencing the growth process. J. Small Bus. Enterp. Dev. 2009, 16, 270-288. [CrossRef]

163. Mitchelmore, S.; Rowley, J. Entrepreneurial competencies of women entrepreneurs pursuing business growth. J. Small Bus. Enterp. Dev. 2013, 20, 125-142. [CrossRef]

164. Carter, S.; Shaw, E. Women's business ownership: Recent research and policy developments. 2006. Available online: https://strathprints.strath.ac.uk/8962/1/SBS_2006_Report_for_BIS.pdf (accessed on 6 November 2019).

165. Man, T.W.Y.; Lau, T. The context of entrepreneurship in Hong Kong: An investigation through the patterns of entrepreneurial competencies in contrasting industrial environments. J. Small Bus. Enterp. Dev. 2005, 12, 464-481. [CrossRef]

166. Mitchell, J.R.; Shepherd, D.A. To thine own self be true: Images of self, images of opportunity, and entrepreneurial action. J. Bus. Ventur. 2010, 25, 138-154. [CrossRef]

167. Parida, V.; George, N.M.; Lahti, T.; Wincent, J. Influence of subjective interpretation, causation, and effectuation on initial venture sale. J. Bus. Res. 2016, 69, 4815-4819. [CrossRef]

168. Shinnar, R.S.; Giacomin, O.; Janssen, F. Entrepreneurial perceptions and intentions: The role of gender and culture. Entrep. Theory Pract. 2012, 36, 465-493. [CrossRef]

169. Achtenhagen, L. Internationalisation Competence of SME. Entreprenörskapsforum. 2011. Available online: www.entreprenorskapsforum.se (accessed on 4 April 2018).

170. Bellucci, A.; Borisov, A.; Zazzaro, A. Does gender matter in bank-firm relationships? Evidence from small business lending. J. Bank. Financ. 2010, 34, 2968-2984. [CrossRef]

171. Sexton, D.L.; Bowman-Upton, N. Female and male entrepreneurs: Psychological characteristics and their role in gender-related discrimination. J. Bus. Ventur. 1990, 5, 29-36. [CrossRef]

172. Sitkin, S.B.; Weingart, L.R. Determinants of risky decision-making behaviour: A test of the mediating role of risk perceptions and propensity. Acad. Manag. J. 1995, 33, 1573-1592.

173. Wagner, J. What difference a Y makes-Female and male nascent entrepreneurs in Germany. Small Bus. Econ. 2007, 28, 1-21. [CrossRef]

174. Verheul, I.; Uhlaner, L.; Thurik, R. Business Accomplishments, Gender and Entrepreneurial Self-Image; SCALES-paper N200312; EIM Business and Policy Research: Zoetermeer, The Netherlands, 2003.

175. Tsyganova, T.; Shirokova, G. Gender differences in entrepreneurship: Evidence from GEM data. Organ. Mark. Emerg. Econ. 2010, 1, 120-141. [CrossRef]

176. Langowitz, N.; Minniti, M. The entrepreneurial propensity of women. Entrep. Theory Pract. 2007, 31, 341-364. [CrossRef]

177. Cole, R.A.; Mehran, H. Gender and the Availability of Credit to Privately Held Firms: Evidence from the Surveys of Small Business Finance; Federal Reserve Bank of New York: New York, NY, USA, 2009.

178. Avin, R.-M.; Kinney, L.P. Trends in Female Entrepreneurship. In Proceedings of the 23th Annual Conference on Feminist Economics Sponsored by IAFFE, University of Ghana, Accra, Ghana, 27-29 June 2014.

179. Idris, N.; Tan, J. Review of literature on women entrepreneurs. J. Glob. Bus. Soc. Entrep. 2017, 1, 1-11.

180. Maden, C. A gendered lens on entrepreneurship: Women entrepreneurship in Turkey. Gend. Manag. Int. J. 2015, 30, 312-331. [CrossRef]

181. Marlow, S.; Hart, M.; Levie, J.; Shamsul, M.K. Women in Enterprise: A Different Perspective; RBS Group: Edinburgh, UK, 2012.

182. Orser, B.; Riding, A.; Dathan, M.; Stanley, J. Gender Challenges for Women in the Canadian Advanced Technology Sectors. In Proceedings of the Canadian Council of Small Business and Entrepreneurship Conference, Kelwona, BC, Canada, 9 November 2007.

183. Tandrayen-Ragoobur, V.; Kasseeah, H. Is gender an impediment to firm performance? Evidence from small firms in Mauritius. Int. J. Entrep. Behav. Res. 2017, 23, 952-976. [CrossRef]

184. Teoh, W.M.Y.; Chong, S.C. Towards strengthening the development of women entrepreneurship in Malaysia. Gend. Manag. Int. J. 2014, 29, 432-453. [CrossRef]

185. Marlow, S.; Swail, J. Gender, risk and finance: Why can't a woman be more like a man? Entrep. Reg. Dev. 2014, 26, 80-96. [CrossRef] 
186. Jennings, J.; Hughes, K.; Jennings, P.D. The work-family interface strategies of male and female entrepreneurs: Are there any differences? In Women Entrepreneurs and the Global Environment for Growth: A Research Perspective; Brush, C., de Bruin, A., Gatewood, E.J., Henry, C., Eds.; Edward Elgar: Cheltenham, UK; Northampton, MA, USA, 2010; pp. 163-186.

187. Aycan, Z.; Eskin, M. Relative contributions of childcare, spousal support, and organizational support in reducing work-family conflict for men and women: The case of Turkey. Sex Roles 2005, 53, 453-471. [CrossRef]

188. Duxbury, L.E.; Higgins, C.A. Gender differences in work-family conflict. J. Appl. Psychol. 1991, 76, 60-74. [CrossRef]

189. Hill, E.J. Work-family facilitation and conflict, working fathers and mothers, work-family stressors and support. J. Fam. Issues 2005, 26, 793-819. [CrossRef]

190. MacDermid, S.; Seery, B.; Weiss, H. An emotional examination of the work-family interface. In Emotions in the Workplace: Understanding the Structure and Role of Emotions in Organizational Behavior; Lord, R.G., Klimoski, R.J., Kanfer, R., Eds.; Jossey-Bass: San Francisco, CA, USA, 2002; pp. 402-429.

191. Morgan, W.; King, E. The association between work-family guilt and pro- and anti-social work behavior. J. Soc. Issues 2012, 68, 684-703. [CrossRef]

192. Nasurdin, A.M.; Ahmad, N.H.; Zainal, S.R.M. Comparing work-family conflict and facilitation among male and female entrepreneurs in Malesia. Int. J. Bus. Soc. 2013, 14, 149-162.

193. Beutell, N.J. The causes and consequences of work-family synergy: An empirical study in the United States. Int. J. Manag. 2010, 27, 650-664.

194. International Finance Corporation (IFC). Women-owned SMES: A Business Opportunities for Financial Institutions. Pennsylvania Avenue, N.W. Washington. 2014. Available online: www.ifc.org (accessed on 2 February 2017).

(C) 2019 by the authors. Licensee MDPI, Basel, Switzerland. This article is an open access article distributed under the terms and conditions of the Creative Commons Attribution (CC BY) license (http://creativecommons.org/licenses/by/4.0/). 